\title{
The hydrochemistry of plantation spruce forest catchments with brown earth soils, Vyrnwy in mid-Wales
}

\author{
Colin Neal ${ }^{1}$, Brian Reynolds ${ }^{2}$, Margaret Neal ${ }^{1}$ and Bronwen Williams ${ }^{2}$ \\ ${ }^{1}$ Centre for Ecology and Hydrology, Crowmarsh Gifford, Wallingford, OX10 8BB, UK \\ ${ }^{2}$ Centre for Ecology and Hydrology Bangor, University of Wales Bangor, Deiniol Road, Bangor, Gwynedd, LL57 2UP, UK
}

Email for corresponding author: cn@ceh.ac.uk

\begin{abstract}
At Vyrnwy, in mid-Wales, a study of the hydrogeochemistry of two small spruce forested catchments, one a control and one felled midway through the study, shows a classic picture of rainfall inputs damped by the catchment and stream waters the chemistry of which varies as functions of flow and particularly of the supply of more acidic and aluminium-bearing soil water and of more basic and calcic ground waters from the zone where weathering reactions with the bedrock are high. The ground waters are most alkaline although $\mathrm{pH}$ may be depressed due to high dissolved carbon dioxide pressures. Nitrate concentrations increase in the first year after felling and decrease thereafter below those of the control. Water quality changes due to the dominant hydrogeochemical processes show that harvesting raises no significant water quality management issues.
\end{abstract}

Keywords: Gran alkalinity, aluminium, spruce, harvesting, forestry, nutrients, trace elements, Vyrnwy, water quality

\section{Introduction}

With the major introduction of conifer plantations to acidic and acid sensitive catchments in the UK uplands between the two World wars and after the Second World War, there have been concerns over the impacts of harvesting on water quality (UK Government, 1994) as well as on the long-term impacts of forestry rotation cycles on water resources and soil nutrient status (National Assembly for Wales, 2000; Good and Reynolds, 2001). The issue of harvesting is of particular concern now that many of the first generation plantation forests are reaching maturity while the longerterm impacts of replanting need to be considered in relation to issues of sustainability (UK Government, 1994).

Studies over the past ten or more years, particularly in Wales, show that the impacts of harvesting on water quality are small and emphasise the benefit of the current forest management policies and the guidelines of the Forestry Commission. (Neal and Reynolds, 1998a,b). However, stream water acidification remains one of the prime water quality concerns over forest harvesting. High levels of nitrate leached from newly harvested sites can lead to the generation of acidic and aluminium-bearing runoff which can affect freshwater ecosystems adversely. For most forest soils the concerns are small but high nitrate releases from highly productive soils such as brown earths may occur with harvesting.

Much of the research in the UK examining the impacts of forest harvesting on water quality has focussed on streams draining the acid peaty podzol and peaty gley soils used extensively for upland plantation forestry (Neal and Reynolds, 1998a,b). However, significant areas of forestry planted on more freely draining and more 'productive' brown podzolic and brown earth soil types may be extended following changes in land-use policy (e.g. the Common Agricultural Practices, CAP, reform).

This study provides new information on the hydrochemical response to harvesting of catchments dominated by brown podzolic soils. Begun as a large collaborative project funded by the Environment Agency, Natural Environment Research Council, Forest Enterprise and the Forestry Commission reported in Neal and Reynolds $1998 \mathrm{a}, \mathrm{b}$, the work has been continued beyond the original 
timescale. It also complements research for streams in midWales (Neal et al., 2004a,b; Reynolds et al., 2004).

\section{Study area}

Two catchments of area of 2 to 4 ha in the close vicinity of Llyn Vyrnwy in mid-Wales were selected for study (Fig. 1). The catchments were selected on the basis of (a) full catchment cover by mature plantation Sitka spruce, (b) brown podzolic soils overlying Lower Palaeozoic sedimentary rocks and (c) ease of access for borehole establishment and sampling. In detail:

- The clear felled site (VN1) is a moderately steep catchment with a perennial stream; it is located to the northeast of Lake Vyrnwy (NGR SJ036219) and ranges in altitude from about $260 \mathrm{~m}$ to about $480 \mathrm{~m}$ a.s.l. The stream is accessible from a forest road and a borehole (VBH1) was drilled nearby. The catchment was planted entirely with Sitka spruce in 1963 and was thinned in
$1989 / 1990$. Some wind blow damage near the top of the catchment had no significant effect on water quality. The dominant soil is brown podzolic with localized gleying in poorly drained areas on some of the shallower slopes. The site was clear felled in April 1997 and brash of branches, needles and tree stumps was left on site.

- The unfelled control site (VN2) is a steep catchment with a mid-point altitude of $350 \mathrm{~m}$ and a perennial stream flowing into the southern margin of Llyn Vyrnwy (NRG SH982213). The stream is accessible from the roadside along the edge of the lake, and a small lay-by provided a site for a borehole (VBH2) for ground water sampling. The catchment is covered by brown podzolic soils and forested by Sitka spruce planted in 1943 and 1955 along with a small area of Japanese larch. No significant wind blow occurred in the catchment.

- Bulk precipitation chemistry was monitored at a site on acid moorland vegetation just outside the forest (NRG SJ000190) using a continuously open collector.

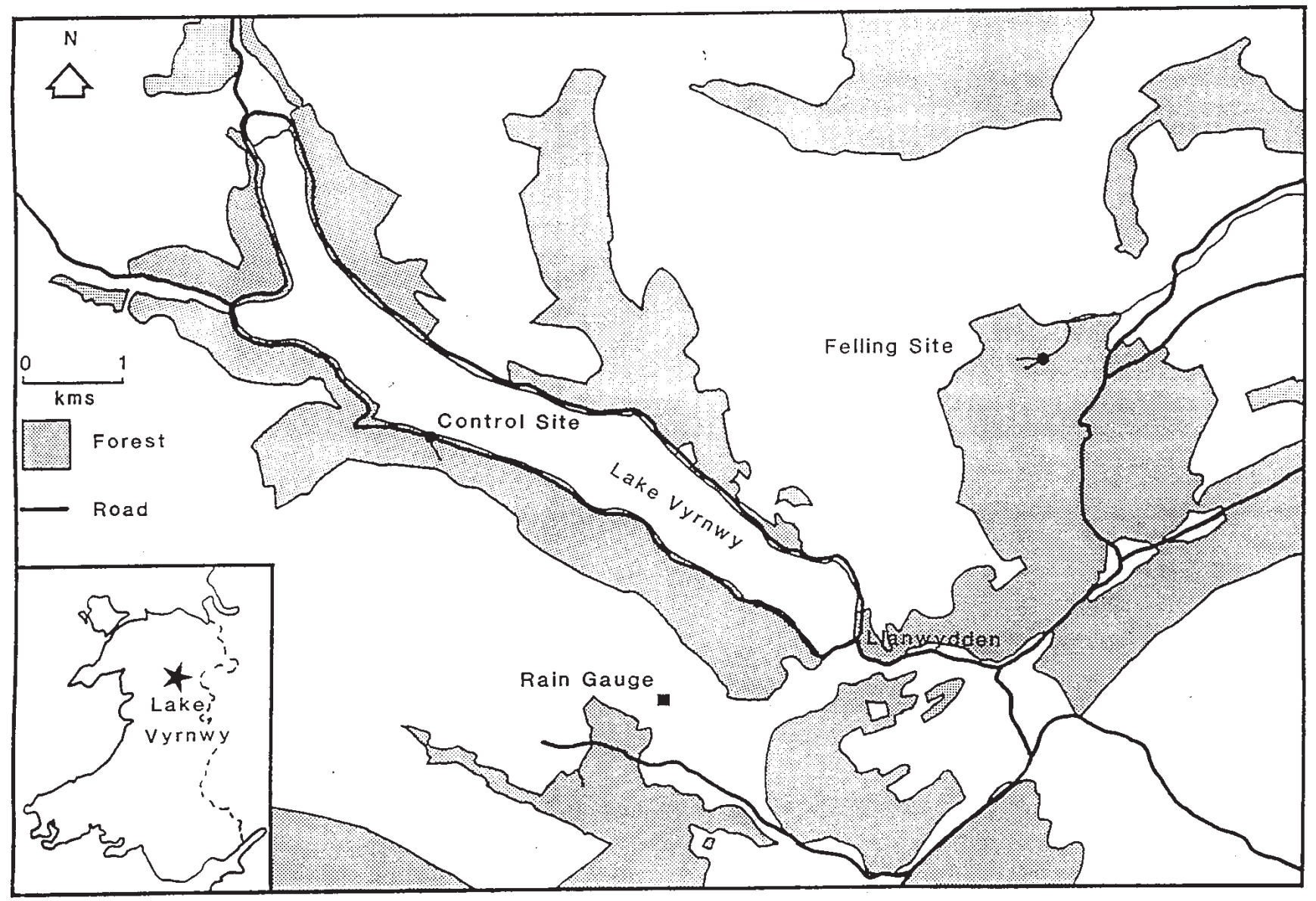

Fig. 1. Location map of the Vyrnwy catchments. Note that the study areas are relatively small as can be gauged from the size of the control and felled streams as indicated in the diagram. The boreholes for monitoring groundwater were close to the stream monitoring point: monitoring points are located in the diagram as 'dots'. 


\section{Methodology}

Samples of stream water, ground water and bulk precipitation were collected every two weeks from October 1994 to February 2001, except for occasional periods of adverse weather conditions or insufficient staff resources.

Samples collected by local Environment Agency staff were returned immediately to the CEH Plynlimon (Staylittle) laboratory for initial processing; following its closure they were sent to the CEH laboratory in Bangor, north Wales. Immediately on arrival at the laboratory, $\mathrm{pH}$, conductivity and Gran alkalinity were measured on unfiltered subsamples of water. The remaining samples, filtered through $0.45 \mu \mathrm{m}$ membrane filters, were then despatched to $\mathrm{CEH}$ Wallingford for chemical analysis of major, minor, nutrient and trace elements. To avoid deterioration during storage, the samples were kept cool and dark and samples for trace element analysis were acidified. (Neal et al., 1997a). It was unfortunate that determinations of concentrations of $\mathrm{Be}, \mathrm{Co}$, $\mathrm{Mo}, \mathrm{Ni}$ and the lanthanides were discontinued in 1998 because of the terminal failure of the ICPMS facility.

\section{Thermodynamic analysis}

Thermodynamic analysis of the chemical data was undertaken to determine the amount of dissolved carbon dioxide in the waters and the degree to which aluminium concentrations were controlled by the solubility of aluminium hydroxide.

Dissolved carbon dioxide concentrations were examined for two reasons. Firstly, ground waters can contain large quantities of dissolved carbon dioxide and its measurement in stream waters can indicate how much degassing of carbon dioxide to the atmosphere has occurred within the stream (Neal et al., 2000). Secondly, for stream and ground waters with moderate to high Gran alkalinities, it is important to assess the extent to which $\mathrm{pH}$ is regulated by the dissolved carbon dioxide content of the water (Neal et al., 1997b, 2000). In this study, the dissolved carbon dioxide levels were estimated from the $\mathrm{pH}$ and Gran alkalinity measurements using the methodology described by Neal et al. (1998a). Amounts of dissolved carbon dioxide are expressed in terms of an excess partial pressure $\left(\mathrm{EpCO}_{2}\right)$ relative to that at equilibrium between pure water and the atmosphere.

Aluminium hydroxide solubility controls have often been inferred for acidic waters in the UK uplands. There is some evidence to suggest such a control for less acidic waters but under more acidic conditions, where there is an insufficient source of aluminium, the waters become undersaturated (Neal and Christophersen, 1989). The ALCHEMI model (Schecher and Driscoll, 1988) has been used to calculate the degree of saturation expressed in terms of a saturation index. This is logarithmic so that values of $-1,0$ and +1 represent a tenth saturation, saturation and ten times saturation, respectively. A value of zero corresponds to an equilibrium state while negative values mean that aluminium hydroxide may dissolve in the waters and positive values imply that the waters may precipitate aluminium hydroxide.

\section{Results}

The water quality data for the Vyrnwy sites are summarised as arithmetic means for the entire study period in Table 1, while Appendix Tables 1, 2 and 3 provide median values and ranges. One rainfall data point was excluded because it had very high nitrate, ammonium, potassium and Gran alkalinity concentrations (2 to 80 times the next highest concentration). Such a high concentration is characteristic of sample contamination from bird droppings (viz. nitrate and ammonium concentrations in the anomalous case were $165 \mathrm{mg}^{-\mathrm{NO}_{3}} \mathrm{l}^{-1}$ and $71 \mathrm{mg}-\mathrm{NH}_{4} \mathrm{l}^{-1}$, respectively).

\section{RAINFALL}

Rainfall is predominantly acidic (mean $\mathrm{pH}$ 5.3) but occasionally more alkaline conditions pertain and the $\mathrm{pH}$ ranges from 3.9 to 7.4 . The waters are generally dilute but there is substantial variation in the concentrations of most determinands measured on a relative basis (an order of magnitude or more). The rainfall chemistry reflects both pollutant and maritime inputs and the variations reflect the predominant wind direction and the location of the various sources. Of the trace elements present, which are mainly from pollutant sources, aluminium, iron, lead and zinc are predominant and they have concentrations of up to $110 \mu \mathrm{g}^{-1}$. Of the major ions, sodium and chloride are of importance and this comes about due to the inputs of maritime components when the main wind direction is from the Atlantic Ocean.

For many components, the highest concentrations occur when rainfall volumes are low (Table 2); this implies scavenging of fine particles from the atmosphere with little dilution by rain water as well as dry deposition directly to the collector surface. The solutes most affected are $\mathrm{K}, \mathrm{NH}_{4}$ and $\mathrm{NO}_{3}$ with tenfold or more differences in concentration between large and small volumes of rainfall.

Factor analysis and graphical approaches have been undertaken to examine the nature of the relationships between the chemical determinands. For the factor analysis, an orthogonal rotation method that minimises the number of variables which have high loadings on each factor 
The hydrochemistry of plantation spruce forest catchments with brown earth soils, Vyrnwy in mid-Wales

Table 1 Average chemistry in rainfall, stream and ground water: monitoring period October 1994 to February 2001.

\begin{tabular}{|c|c|c|c|c|c|c|}
\hline & & $\begin{array}{l}\text { Average } \\
\text { Rainfall }\end{array}$ & $\begin{array}{l}\text { Average } \\
\text { Stream: Felling }\end{array}$ & $\begin{array}{l}\text { Average } \\
\text { Stream: Control }\end{array}$ & $\begin{array}{l}\text { Average } \\
\text { Borehole: Felling }\end{array}$ & $\begin{array}{l}\text { Average } \\
\text { Borehole: Control }\end{array}$ \\
\hline $\mathrm{Na}$ & $\mathrm{mg} \mathrm{l}^{-1}$ & 1.93 & 5.23 & 5.75 & 5.86 & 7.3 \\
\hline K & $\mathrm{mg} \mathrm{l}^{-1}$ & 0.29 & 0.36 & 0.33 & 0.91 & 0.34 \\
\hline $\mathrm{Ca}$ & $\mathrm{mg} \mathrm{l}^{-1}$ & 0.82 & 3.66 & 3.06 & 9.52 & 5.45 \\
\hline $\mathrm{Mg}$ & $\mathrm{mg} \mathrm{l}^{-1}$ & 0.32 & 1.20 & 1.85 & 3.11 & 2.93 \\
\hline $\mathrm{NH}_{4}$ & $m g-\mathrm{NH}_{4} 1^{-1}$ & 0.88 & 0.04 & 0.03 & 0.05 & 0.02 \\
\hline $\mathrm{Cl}$ & $\mathrm{Mg} \mathrm{l}^{-1}$ & 4.26 & 8.6 & 9.3 & 9.0 & 11.6 \\
\hline $\mathrm{SO}_{4}$ & $\mathrm{mg}-\mathrm{SO}_{4} \mathrm{l}^{-1}$ & 2.12 & 8.6 & 8.7 & 11.5 & 12.4 \\
\hline $\mathrm{NO}_{3}$ & $m g-\mathrm{NO}_{3} 1^{-1}$ & 2.27 & 2.23 & 2 & 9.39 & 1.03 \\
\hline $\mathrm{F}^{3}$ & $\mathrm{Mg} \mathrm{l}^{-1}$ & 0.02 & 0.05 & 0.04 & 0.07 & 0.04 \\
\hline $\mathrm{Br}$ & $\mu \mathrm{g}^{-1}$ & 11.8 & 42 & 32 & 42 & 47 \\
\hline I & $\mu \mathrm{gl}^{-1}$ & 1.1 & 1.55 & 0.81 & 2.02 & 0.66 \\
\hline $\mathrm{PO}_{4}$ & $\mathrm{mg}-\mathrm{Pl}^{-1}$ & 0.03 & 0.01 & 0.01 & 0.05 & 0.01 \\
\hline DOC & $\mathrm{mg}^{-1}$ & 1.09 & 1.9 & 1.4 & 0.8 & 1.1 \\
\hline $\mathrm{Si}$ & $\mathrm{mg} \mathrm{l}^{-1}$ & 0.11 & 1.8 & 1.9 & 1.9 & 2.3 \\
\hline $\mathrm{pH}$ & & 5.34 & 6.29 & 6.71 & 6.02 & 7 \\
\hline G. Alk & $\mu \mathrm{Eq} 1^{-1}$ & 41 & 50 & 77 & 361 & 230 \\
\hline ANC & $\mu \mathrm{Eq} 1^{-1}$ & -42 & 62 & 83 & 368 & 239 \\
\hline $\mathrm{EpCO}_{2}$ & atmos & na & 4 & 2 & 54 & 4.2 \\
\hline $\mathrm{Al}$ & $\mu \mathrm{gl}^{-1}$ & 16.0 & 82.9 & 38.7 & 15.7 & 26.4 \\
\hline B & $\mu \mathrm{gl}^{-1}$ & 3.3 & 7.7 & 5.9 & 13.9 & 7.4 \\
\hline $\mathrm{Ba}$ & $\mu \mathrm{g}^{-1}$ & 1.8 & 6.5 & 3.6 & 9.7 & 0.9 \\
\hline $\mathrm{Be}$ & $\mu \mathrm{gl}^{-1}$ & 0.0 & 0.0 & 0.0 & 0.1 & 0.0 \\
\hline $\mathrm{Cd}$ & $\mu \mathrm{gl}^{-1}$ & 0.4 & 0.2 & 0.2 & 0.3 & 0.2 \\
\hline $\mathrm{Ce}$ & $\mu \mathrm{g}^{-1}$ & 0.0 & 0.1 & 0.0 & 0.0 & 0.1 \\
\hline Co & $\mu \mathrm{gl}^{-1}$ & 0.1 & 0.2 & 0.1 & 0.4 & 0.1 \\
\hline $\mathrm{Cr}$ & $\mu \mathrm{gl}^{-1}$ & 3.9 & 0.2 & 0.2 & 0.1 & 0.2 \\
\hline Cs & $\mu \mathrm{gl}^{-1}$ & 0.0 & 0.0 & 0.2 & 0.1 & 0.3 \\
\hline $\mathrm{Cu}$ & $\mu \mathrm{g}^{-1}$ & 2.8 & 2.1 & 1.7 & 3.0 & 3.6 \\
\hline $\mathrm{Fe}$ & $\mu \mathrm{gl}^{-1}$ & 19.8 & 50.9 & 60.8 & 18.2 & 35.6 \\
\hline $\mathrm{La}$ & $\mu \mathrm{gl}^{-1}$ & 0.0 & 0.1 & 0.1 & 0.0 & 0.0 \\
\hline $\mathrm{Li}$ & $\mu \mathrm{gl}^{-1}$ & 0.1 & 0.8 & 1.0 & 1.8 & 1.2 \\
\hline $\mathrm{Mn}$ & $\mu \mathrm{gl}^{-1}$ & 5.7 & 10.0 & 6.9 & 18.1 & 3.2 \\
\hline Mo & $\mu \mathrm{g} \mathrm{l}^{-1}$ & 0.1 & 0.1 & 0.1 & 0.2 & 0.2 \\
\hline $\mathrm{Ni}$ & $\mu \mathrm{gl}^{-1}$ & 1.5 & 1.4 & 1.5 & 3.0 & 1.5 \\
\hline $\mathrm{Pb}$ & $\mu \mathrm{gl}^{-1}$ & 92.0 & 0.2 & 0.8 & 0.2 & 0.3 \\
\hline $\operatorname{Pr}$ & $\mu \mathrm{g} \mathrm{l}^{-1}$ & 0.0 & 0.0 & 0.1 & 0.0 & 0.0 \\
\hline $\mathrm{Rb}$ & $\mu \mathrm{gl}^{-1}$ & 0.2 & 0.3 & 0.5 & 1.0 & 0.4 \\
\hline $\mathrm{Sb}$ & $\mu \mathrm{g}^{-1}$ & 0.2 & 0.1 & 2.5 & 0.3 & 0.1 \\
\hline $\mathrm{Sc}$ & $\mu \mathrm{gl}^{-1}$ & 0.0 & 0.7 & 0.7 & 0.8 & 0.8 \\
\hline $\mathrm{Sr}$ & $\mu \mathrm{g} \mathrm{l}^{-1}$ & 2.8 & 11.0 & 11.2 & 19.4 & 19.9 \\
\hline Th & $\mu \mathrm{g}^{-1}$ & 0.0 & 0.0 & 0.1 & 0.0 & 0.0 \\
\hline $\mathrm{U}$ & $\mu \mathrm{gl}^{-1}$ & 0.0 & 0.0 & 1.0 & 0.1 & 0.0 \\
\hline $\mathrm{Y}$ & $\mu \mathrm{g} \mathrm{l}^{-1}$ & 0.0 & 0.2 & 0.1 & 0.2 & 0.1 \\
\hline $\mathrm{Zn}$ & $\mu \mathrm{gl}^{-1}$ & 19.4 & 9.5 & 8.4 & 17 & 9.4 \\
\hline
\end{tabular}


Table 2. Low/baseflow and high/stormflow chemistries: monitoring period October 1994 to February 2001.

\begin{tabular}{|c|c|c|c|c|c|c|c|c|c|c|c|}
\hline & & \multicolumn{2}{|c|}{ Rain } & \multirow{2}{*}{$\begin{array}{l}\text { Stream. } \\
\text { Low }\end{array}$} & Felling & \multirow{2}{*}{$\begin{array}{l}\text { Stream. } \\
\text { Low }\end{array}$} & \multirow{2}{*}{$\begin{array}{c}\text { Control } \\
\text { High }\end{array}$} & \multirow{2}{*}{$\begin{array}{l}\text { Stream: } \\
\text { Low }\end{array}$} & \multirow{2}{*}{$\begin{array}{c}\text { Felling } \\
\text { High }\end{array}$} & \multirow{2}{*}{$\begin{array}{l}\text { Stream: } \\
\text { Low }\end{array}$} & \multirow{2}{*}{$\begin{array}{l}\text { Control } \\
\text { High }\end{array}$} \\
\hline & & Low & High & & High & & & & & & \\
\hline $\mathrm{Na}$ & $\mathrm{mg} \mathrm{l}^{-1}$ & 2.20 & 3.63 & 5.60 & 5.19 & 6.11 & 5.59 & 5.59 & 5.32 & 7.53 & 7.13 \\
\hline $\mathrm{K}$ & $\mathrm{mg} \mathrm{l}^{-1}$ & 0.89 & 0.16 & 0.31 & 0.56 & 0.42 & 0.35 & 1.34 & 0.74 & 0.39 & 0.28 \\
\hline $\mathrm{Ca}$ & $\mathrm{mg} \mathrm{l}^{-1}$ & 1.13 & 0.67 & 4.03 & 3.37 & 4.03 & 2.11 & 13.92 & 7.54 & 7.48 & 4.47 \\
\hline $\mathrm{Mg}$ & $\mathrm{mg} \mathrm{l}^{-1}$ & 0.41 & 0.49 & 1.18 & 1.29 & 2.39 & 1.32 & 5.53 & 1.98 & 3.86 & 2.41 \\
\hline $\mathrm{NH}_{4}$ & $\mathrm{mg}-\mathrm{NH}_{4} \mathrm{l}^{-1}$ & 3.81 & 0.21 & 0.05 & 0.02 & 0.02 & 0.04 & 0.05 & 0.03 & 0.02 & 0.01 \\
\hline $\mathrm{Cl}^{4}$ & $\mathrm{mg} \mathrm{l}^{-1}$ & 4.48 & 6.52 & 8.98 & 9.26 & 9.15 & 9.84 & 8.30 & 6.15 & 12.39 & 9.92 \\
\hline $\mathrm{SO}_{4}$ & $\mathrm{mg}-\mathrm{SO}_{4} \mathrm{l}^{-1}$ & 3.02 & 1.62 & 8.52 & 7.92 & 10.81 & 6.12 & 12.08 & 10.76 & 14.48 & 11.21 \\
\hline $\mathrm{NO}_{3}$ & $\mathrm{mg}-\mathrm{NO}_{3} \mathrm{l}^{-1}$ & ${ }^{1} 12.08$ & 0.48 & 1.93 & 3.59 & 1.59 & 2.62 & 8.46 & 9.79 & 0.44 & 1.28 \\
\hline $\mathrm{F}$ & $\mathrm{mg} \mathrm{l}^{-1}$ & 0.01 & 0.01 & 0.07 & 0.06 & 0.05 & 0.04 & 0.10 & 0.05 & 0.04 & 0.02 \\
\hline $\mathrm{Br}$ & $\mu \mathrm{g}^{-1}$ & 8.50 & 17.67 & 56.17 & 36.57 & 35.00 & 32.43 & 46.57 & 35.83 & 49.71 & 36.17 \\
\hline I & $\mu \mathrm{g}^{-1}$ & 1.95 & 0.63 & 1.97 & 1.44 & 0.82 & 0.86 & 7.91 & 1.55 & 0.94 & 0.57 \\
\hline $\mathrm{PO}_{4}$ & $\mathrm{mg}-\mathrm{P}^{-1}$ & 0.00 & 0.00 & 0.03 & 0.01 & 0.02 & 0.01 & 0.06 & 0.05 & 0.01 & 0.00 \\
\hline DOC & $\mathrm{mg} \mathrm{l}^{-1}$ & 1.80 & 0.58 & 2.15 & 1.64 & 1.58 & 1.29 & 0.66 & 0.83 & 1.23 & 1.18 \\
\hline $\mathrm{Si}$ & $\mathrm{mg} \mathrm{l}^{-1}$ & 0.08 & 0.13 & 1.77 & 1.58 & 1.98 & 1.39 & 2.85 & 1.35 & 2.99 & 1.93 \\
\hline $\mathrm{pH}$ & & 5.60 & 5.16 & 6.50 & 5.79 & 6.98 & 6.03 & 6.23 & 5.91 & 7.11 & 6.95 \\
\hline G. Alk & $\mu \mathrm{Eq} 1^{-1}$ & 174 & 4 & 76 & 23 & 145 & 22 & 780 & 254 & 282 & 246 \\
\hline ANC & $\mu \mathrm{Eq} 1^{-1}$ & -2 & 11 & 86 & 30 & 168 & 19 & 903 & 381 & 371 & 205 \\
\hline $\mathrm{EpCO}_{2}$ & atmos & na & na & 2 & 3 & 3 & 5 & 76 & 53 & 3 & 5 \\
\hline $\mathrm{Al}$ & $\mu \mathrm{g}^{-1}$ & 5.3 & 16.4 & 57.8 & 127.4 & 22.6 & 80.1 & 4.0 & 22.1 & 148.3 & 15.3 \\
\hline B & $\mu \mathrm{gl}^{-1}$ & 4.4 & 3.1 & 9.3 & 7.3 & 6.9 & 6.3 & 14.4 & 12.7 & 7.9 & 7.4 \\
\hline $\mathrm{Ba}$ & $\mu \mathrm{g}^{-1}$ & 2.3 & 1.8 & 5.2 & 9.0 & 3.5 & 4.7 & 11.3 & 7.6 & 0.7 & 1.3 \\
\hline $\mathrm{Be}$ & $\mu \mathrm{gl}^{-1}$ & 0.0 & 0.1 & 0.1 & 0.2 & 0.1 & 0.1 & 0.0 & 0.1 & 0.0 & 0.0 \\
\hline $\mathrm{Cd}$ & $\mu \mathrm{gl}^{-1}$ & 0.5 & 0.1 & 0.2 & 0.2 & 0.2 & 0.3 & 0.1 & 0.4 & 0.1 & 0.3 \\
\hline $\mathrm{Ce}$ & $\mu \mathrm{g}^{-1}$ & 0.0 & 0.0 & 0.1 & 0.2 & 0.0 & 0.0 & 0.0 & 0.0 & 0.1 & 0.0 \\
\hline Co & $\mu \mathrm{gl}^{-1}$ & 0.0 & 0.0 & 0.1 & 0.5 & 0.1 & 0.4 & 1.4 & 0.3 & 0.0 & 0.0 \\
\hline $\mathrm{Cr}$ & $\mu \mathrm{gl}^{-1}$ & 2.8 & 0.9 & 0.1 & 0.1 & 0.1 & 0.1 & 0.1 & 0.1 & 0.1 & 0.0 \\
\hline Cs & $\mu \mathrm{g}^{-1}$ & 0.0 & 0.0 & 0.0 & 0.0 & 0.0 & 0.0 & 0.0 & 0.2 & 0.0 & 0.0 \\
\hline $\mathrm{Cu}$ & $\mu \mathrm{gl}^{-1}$ & 3.0 & 1.6 & 2.9 & 2.6 & 2.7 & 1.5 & 3.6 & 2.8 & 4.1 & 4.2 \\
\hline $\mathrm{Fe}$ & $\mu \mathrm{gl}^{-1}$ & 21.3 & 19.8 & 34.3 & 64.3 & 31.5 & 60.7 & 7.7 & 17.2 & 198.3 & 17.5 \\
\hline $\mathrm{La}$ & $\mu \mathrm{g} \mathrm{l}^{-1}$ & 0.0 & 0.0 & 0.1 & 0.1 & 0.0 & 0.1 & 0.0 & 0.0 & 0.0 & 0.0 \\
\hline $\mathrm{Li}$ & $\mu \mathrm{g}^{-1}$ & 0.2 & 0.1 & 0.5 & 1.2 & 0.9 & 1.2 & 2.4 & 0.8 & 2.0 & 1.2 \\
\hline $\mathrm{Mn}$ & $\mu \mathrm{gl}^{-1}$ & 5.3 & 4.3 & 4.6 & 42.4 & 3.2 & 32.5 & 160.8 & 6.6 & 17.3 & 2.1 \\
\hline Mo & $\mu g 1^{-1}$ & 0.1 & 0.0 & 0.0 & 0.0 & 0.0 & 0.0 & 0.1 & 0.2 & 0.1 & 0.5 \\
\hline $\mathrm{Ni}$ & $\mu \mathrm{g}^{-1}$ & 0.8 & 1.4 & 1.3 & 1.8 & 1.5 & 2.2 & 4.4 & 1.7 & 1.6 & 1.2 \\
\hline $\mathrm{Pb}$ & $\mu \mathrm{gl}^{-1}$ & 24.1 & 28.4 & 0.4 & 0.3 & 0.7 & 0.2 & 0.5 & 0.1 & 0.1 & 0.0 \\
\hline $\operatorname{Pr}$ & $\mu \mathrm{gl}^{-1}$ & 0.0 & 0.0 & 0.0 & 0.0 & 0.0 & 0.0 & 0.0 & 0.0 & 0.0 & 0.0 \\
\hline $\mathrm{Rb}$ & $\mu g \mathrm{l}^{-1}$ & 0.1 & 0.1 & 0.3 & 0.3 & 0.5 & 0.4 & 0.8 & 1.0 & 0.4 & 0.4 \\
\hline $\mathrm{Sb}$ & $\mu \mathrm{gl}^{-1}$ & 0.1 & 0.0 & 0.1 & 0.3 & 0.1 & 0.1 & 0.4 & 0.1 & 0.1 & 0.0 \\
\hline $\mathrm{Sc}$ & $\mu \mathrm{g}^{-1}$ & 0.0 & 0.0 & 0.7 & 0.6 & 0.8 & 0.5 & 1.0 & 0.7 & 1.4 & 0.8 \\
\hline $\mathrm{Sr}$ & $\mu \mathrm{gl}^{-1}$ & 3.7 & 3.4 & 11.0 & 10.7 & 14.1 & 8.7 & 14.8 & 17.6 & 21.5 & 18.4 \\
\hline $\mathrm{Th}$ & $\mu \mathrm{g}^{-1}$ & 0.2 & 0.0 & 0.0 & 0.0 & 0.0 & 0.0 & 0.1 & 0.0 & 0.1 & 0.2 \\
\hline $\mathrm{U}$ & $\mu \mathrm{gl}^{-1}$ & 0.0 & 0.0 & 0.0 & 0.0 & 0.0 & 0.0 & 0.1 & 0.0 & 0.0 & 0.0 \\
\hline $\mathrm{Y}$ & $\mu g \mathrm{l}^{-1}$ & 0.0 & 0.0 & 0.2 & 0.3 & 0.1 & 0.2 & 0.1 & 0.2 & 0.1 & 0.1 \\
\hline $\mathrm{Zn}$ & $\mu \mathrm{g}^{-1}$ & 16.7 & 16.2 & 9.0 & 14.7 & 11.7 & 10.4 & 12.7 & 17.2 & 5.7 & 11.2 \\
\hline
\end{tabular}


(Varimax method) simplifies the interpretation of factors and resulted in six groupings; one is linked in part to maritime sources and the others to terrestrial pollutant inputs. Graphs of these six groupings (Fig. 2) show:

1. $\mathrm{Na}, \mathrm{Mg}, \mathrm{Sr}, \mathrm{Cl}, \mathrm{pH}, \mathrm{Gran}$ alkalinity and $\mathrm{ANC}(10 \%$ of the variance explained). This group is related negatively to all the others; it represents in part the oceanic (sea salt) endmember of the system while the high $\mathrm{pH}$, Gran alkalinity and ANC reflect the lack of strong acid anions

\section{Cl vs Na}

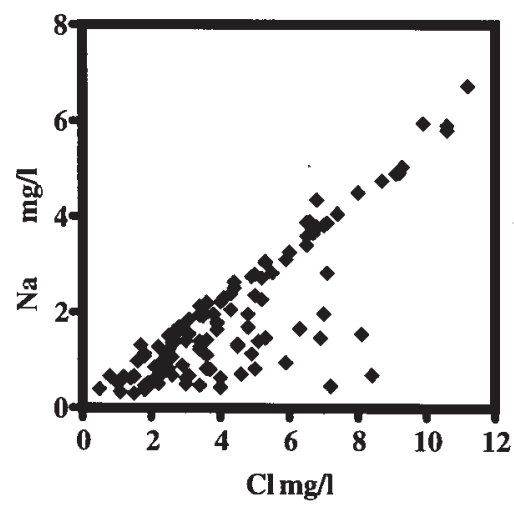

SO4 vs NH4

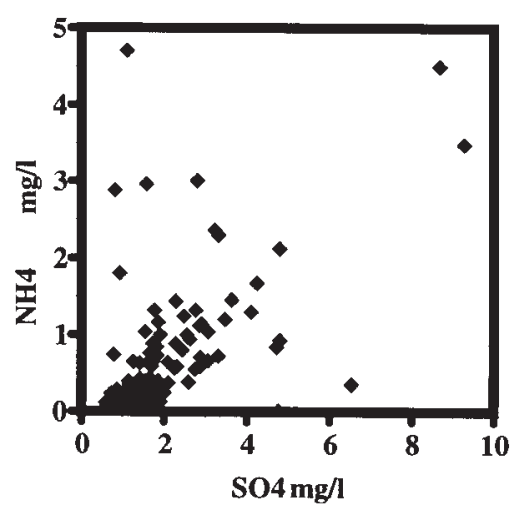

K vs B

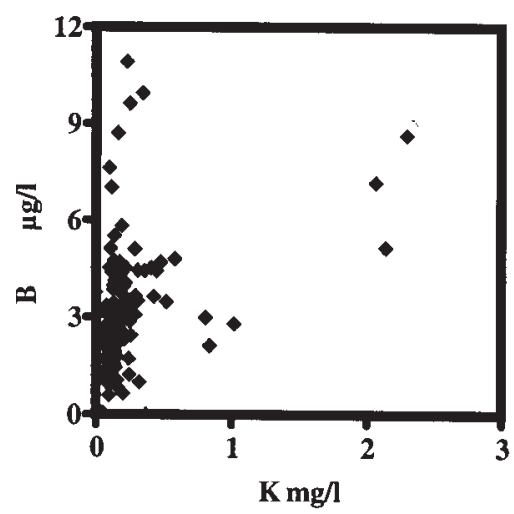

$\left(\mathrm{SO}_{4}\right.$ and $\mathrm{NO}_{3}$ ) associated with acid deposition. While there are linear relations for the sea salt components, there is higher scatter at lower concentrations. This higher scatter probably reflects some additional pollutant sources. Figure 2 shows a plot of $\mathrm{Cl}$ against $\mathrm{Na}$ as a straight line (corresponding to that for sea salts) but with clear systematic deviations at higher chloride concentrations, probably because of pollutant chloride inputs.

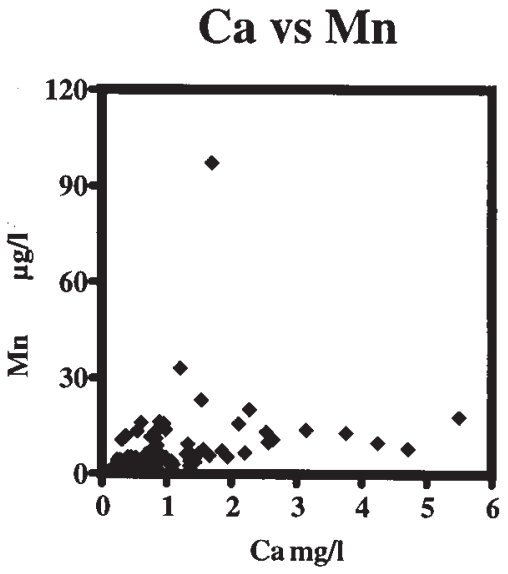

Fe vs Al

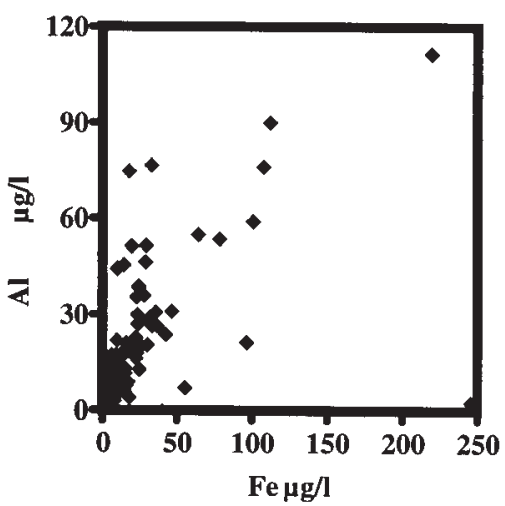

Zn vs Co

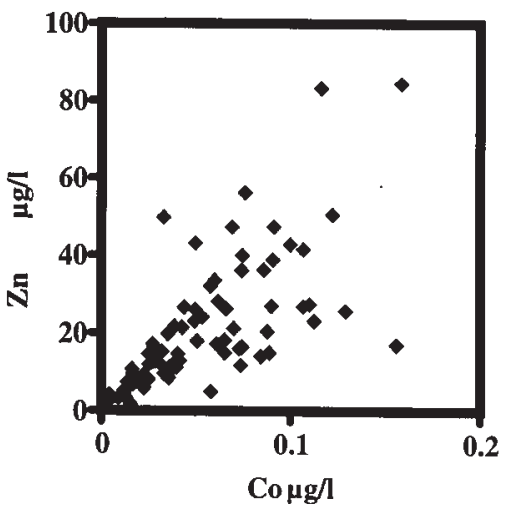

Fig. 2. Inter-element plots illustrating six dominant patterns of behaviour in Vyrnwy rainfall: monitoring period October 1994 to February 2001. 
2. Ca, Mn, Cr, Sr, Mo, Cd, Ba, Pb and DOC (19\% of variance explained). Of this group of pollutants, $\mathrm{Cr}$ and $\mathrm{Pb}$ occur in association with small rainfall events in midWales although their origin is unclear (Neal et al., 1996). For this entire group, a marked dilution with increasing rainfall volume is characteristic of atmospheric scavenging. This behaviour contrasts with the pollutant groups (3 to 6, below) where very little volume dilution occurs except, perhaps, for group 4.

3. $\mathrm{SO}_{4}, \mathrm{DOC}, \mathrm{NO}_{3}, \mathrm{NH}_{4}$ and $-\mathrm{ANC}(12 \%$ of the variance explained). Of these, $\mathrm{SO}_{4}, \mathrm{NO}_{3}$ and $\mathrm{NH}_{4}$ show the most significant correlations, but with significant scatter around a linear trend (Fig. 2). These are the major acidifying agents associated with acidic oxide generation from industry and power generation $\left(\mathrm{NO}_{\mathrm{x}}\right.$ and $\left.\mathrm{SO}_{\mathrm{x}}\right)$, car exhausts $\left(\mathrm{NO}_{\mathrm{x}}\right)$ and farming $\left(\mathrm{NH}_{3}\right)$. DOC will also come from industrial emissions while the negative relationship with ANC reflects the high concentrations of $\mathrm{SO}_{4}$ and $\mathrm{NO}_{3}$.

4. Fe, Al, Zn, Cd, Ba, -pH, -Gran alkalinity and -ANC ( $13 \%$ of the variance explained). This grouping of trace metal pollutants is associated with industrial emissions. Most of the metals involved are of high charge and relatively low solubility. They dissolve under acidic conditions, partly neutralising the acidity in the process. There is less clear cut evidence of a dilution effect as for group 2.

5. $\mathrm{K}, \mathrm{B}, \mathrm{Cu}, \mathrm{Rb}$ and $\mathrm{I}$ ( $11 \%$ of the variance explained). This group represents an agricultural input in terms of $\mathrm{K}$ and $\mathrm{B}$ (although there may be a significant $\mathrm{B}$ input in maritime sources). However, it is unclear why $\mathrm{Cu}$ and $\mathrm{Rb}$ occur in this group (perhaps they are connected with trace components in fertilizers and mineral supplements for livestock). Iodine also occurs in this group and, while it is usually associated with maritime sources, it is not correlated with the sea salts because of additional fractionation at the sea-atmosphere interface.

6. $\mathrm{Be}, \mathrm{Ni}, \mathrm{Co}$ and $\mathrm{Zn}$ (7\% of the variance is explained). This is another set of industrial pollutants, for which the concentrations seem to increase over time.

For groupings 2 to 6 , linear positive relationships are observed between group members; these correspond to mixing behaviours between pollutant and non-pollutant sources. However, scatter increases with concentration (Fig. 2 ). Hence, for each of these groups, the composition of the pollutant inputs varies as do the inter-element relationships for each group member. This, in turn, implies that there is more than one pollutant source for the components in a particular group.

\section{STREAM WATER}

Stream water chemistry is dilute and of a calcium bicarbonate and sodium chloride type. The calcium bicarbonate comes from weathering of the bedrock while the sodium and chloride come from atmospheric inputs of sea salts. The waters are moderately acidic to slightly alkaline with $\mathrm{pH}$ in the range of 5.4 to 7.5 . Gran alkalinity varies between 2 and $216 \mu \mathrm{Eq} \mathrm{l}^{-1}$ and the carbon dioxide partial pressures tend to be slightly above atmospheric pressure (felled-site, average $=4$, range $=1$ to 22 ; control site, average $=2$, range $=1$ to 13 ). Of the trace elements, Al and $\mathrm{Fe}$ have the highest concentrations ranging from 8 to $202 \mu \mathrm{g}^{-1}$ and 9 to $1312 \mu \mathrm{g} \mathrm{l^{-1 }}$, respectively.

Mean and ranges of chemical concentrations are highly correlated between the two sites. In Fig. 3a, mean concentration and its logarithm for the various determinands in the stream waters (the comparable data for the ground waters are in Fig. 3b) show strong linear relationships, which correspond to linear regression equations of

$$
\begin{gathered}
\text { Stream }_{\text {control }}= \\
\begin{array}{c}
1.04 \pm 0.04 * \text { Stream }_{\text {felling }}-0.0 \pm 0.5 \\
\mathrm{r}^{2}=0.991, \mathrm{~N}=34
\end{array}
\end{gathered}
$$

\section{Stream: felling vs control}

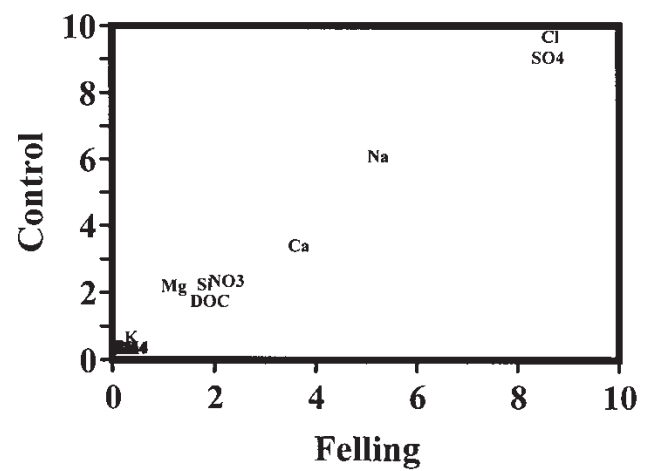

\section{Stream: log Felling vs control}

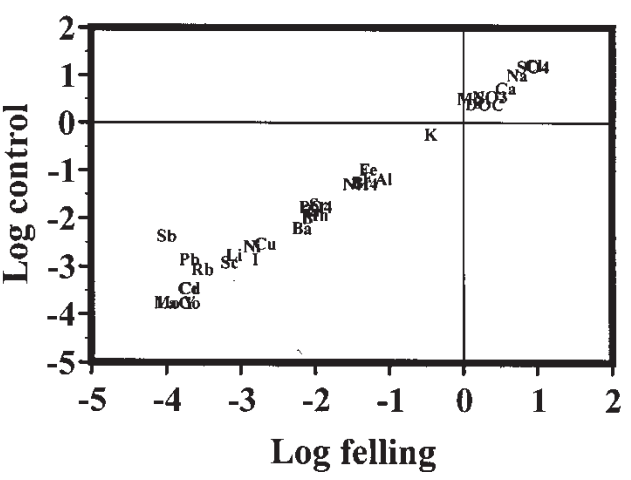

Fig. 3a. Plots of average concentration for the various determinands (in concentration units of $\mathrm{mg}^{-1}$ ) for stream water using both linear and logarithmic scaling: monitoring period October 1994 to February 2001 


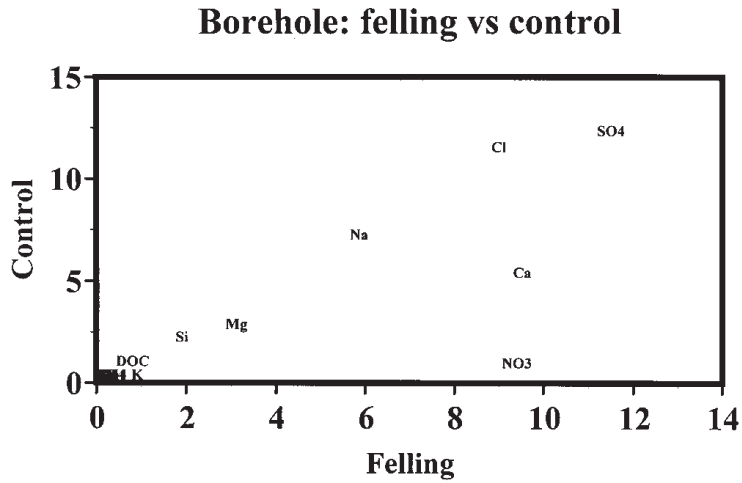

Borehole: log felling vs control

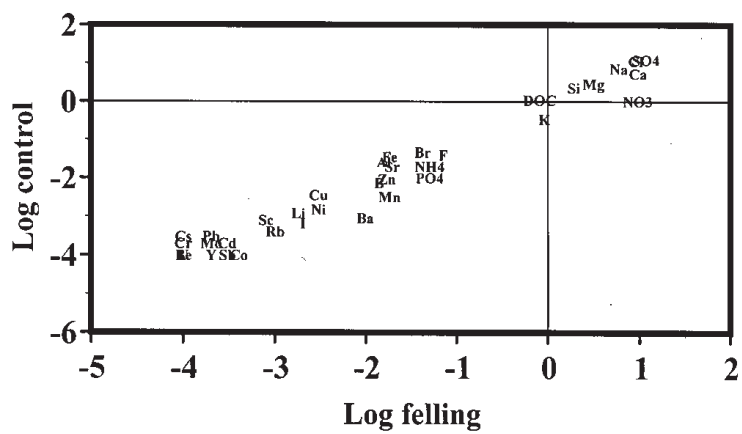

Fig. 3b. Plots of average concentration for the various determinands (in concentration units of $\mathrm{mg} \mathrm{l}^{-1}$ ) in ground water using both linear and logarithmic scaling: monitoring period October 1994 to February 2001.

and

$$
\begin{gathered}
\log \left(\text { Stream }_{\text {control }}\right)=0.96 \pm 0.05 * \log \left(\text { Stream }_{\text {fell }}\right)-0.0 \pm 0.6 \\
r^{2}=0.967, N=34
\end{gathered}
$$

For these equations, the \pm sign indicates twice the standard error. Both linear and logarithmic plots are provided to show the spread in absolute concentration on a linear scale and the relative spread on a logarithmic scale (the logarithmic scale puts equal emphasis on trace and major components). In both plots, gradients do not differ significantly from unity while, for the unlogged regression, the intercept is not significantly different from zero. The two sets of data are, therefore, broadly similar in relative and absolute terms. Nevertheless, there are some differences as shown in Table 1 and in the Appendix Figs. 1 to 4. Thus, Gran alkalinity, $\mathrm{ANC}$ and $\mathrm{Mg}$ concentrations are generally higher in the control stream (VN2), while $\mathrm{Al}, \mathrm{Ba}, \mathrm{Be}, \mathrm{Br}$ and I concentrations are generally higher in the stream draining the felled site (VN1) even before felling commenced.

The concentrations of a limited number of components vary as a function of flow, time and felling. The main features of this variation are as follows.

\section{FLOW RESPONSE FOR THE STREAMS}

There are two types of flow response for the streams.

1. For $\mathrm{Al}, \mathrm{Fe}, \mathrm{Mn}$ and $\mathrm{NO}_{3}$, which are linked to the soils where more acidic conditions prevail and where low solubility minerals of $\mathrm{Al}, \mathrm{Fe}$ and $\mathrm{Mn}$ are mobilised, concentrations increase with increasing flow and there is a negative relationship with the first group.

2. For Ca, Gran alkalinity and ANC, associated with bedrock weathering sources, concentrations decline with increasing flow. Although the Lower Palaeozoic geology of the area is typically dominated by fine grained sedimentary rocks containing little calcium (Llandovery and Ashgill series), bands of shelly material (brachiopods, crinoid and coral debris) occur in some of the formations within the Llandovery to the south of Vyrnwy at Llyn Brianne (Mackie, 1987). If these also occur in the Vyrnwy area, they would provide a highly weatherable source of calcium carbonate.

This is consistent with the classic concept of twocomponent mixing between contrasting hydrochemical regimes (Neal and Christophersen, 1989). The components which link to the first type of flow response correspond to inputs from the soil waters that are both acidic and contain easily hydrolysable trace metals. The components which link to this second type of flow response correspond to a shallow ground water input where weathering releases base cations, produces bicarbonate from dissolved carbon dioxide and precipitates the easily hydrolysable elements when they are flushed from the soil zones. The changing stream chemistry reflects the relative contribution of water from each of the end members. This is hydrologically driven; ground water sources dominate base flows and soil waters dominate high flows when the catchments are wetted up.

\section{TEMPORAL PATTERNS FOR THE STREAMS}

Three components show clear long-term patterns of change over time. Firstly, $\mathrm{SO}_{4}$ concentrations are decreasing probably in response to declining atmospheric deposition linked to reductions in industrial $\mathrm{SO}_{2}$ emissions since their peak in the 1970s. In contrast, concentrations of DOC and $\mathrm{Fe}$ increase over time. This is observed for DOC elsewhere in the UK (Monteith and Evans, 2000) and may be linked to climate change and to its effects on the biogeochemistry of organic-rich soils (Freeman et al., 2001). Iron follows a 
similar trend because it is strongly chelated to dissolved organic matter. The coupling of DOC and Fe has been observed previously in soil waters and stream waters in upland catchments in mid-Wales (Hughes et al., 1990, 1998; Neal et al., 2001). Be concentrations also increase over time but the $\mathrm{Be}$ data cover only the first two thirds of the data record: the trend for $\mathrm{Be}$ is observed at a different site in mid-Wales (Neal, 2003).

\section{HYDROCHEMICAL RESPONSES RELATED TO} FELLING

Five types of response characterise the effects of felling on water quality:

1. The sea salts (Na and $\mathrm{Cl}$ ). Prior to felling, both streams have similar concentrations of these components; subsequently, concentrations at the felled site (VN1) decline relative to the control (VN2) (Appendix Figs. 1 and 2). This occurs because removal of the forest canopy reduces (a) capture of sea salts from mist and aerosols and (b) interception loss of rainfall thereby allowing more water to reach the ground, creating more runoff and leading to increased dilution potential (Neal, 2002a). Nonetheless, there may be an initial rise in concentration following felling.

2. $\mathrm{NO}_{3}$ (and $\mathrm{Ba}$ ). With the disruption of the biogeochemical cycle consequent on felling, soil water and stream water nitrate concentrations almost always increase in UK forests (Neal and Reynolds, 1998a,b; Neal et al., 1998b). At Vyrnwy, nitrate concentrations in VN1 are almost four times those of the control ( 3 to $11 \mathrm{mg}-\mathrm{NO}_{3} \mathrm{l}^{-1}$ ). The increase is for about 12 months through 1997-98 and is at its greatest during the intervening winter. Subsequently, $\mathrm{NO}_{3}$ concentrations fall below those in the control stream. Whilst this probably represents increased uptake into newly developing vegetation, the response is shorter-lived than that found in other studies (c.f. Neal, 2002a,b). The lowest $\mathrm{NO}_{3}$ concentrations both in absolute and relative terms occur during the summer months when nitrogen utilisation by plants would be at a maximum. Ba shows a modest increase in line with $\mathrm{NO}_{3}$. Thus, $\mathrm{Ba}$ is also influenced by felling in a way that the other divalent base cations are not. In fact, Ba is unusual with respect to other members in the group (excepting Be which exhibits other properties linked to its small ion size and ease of hydrolysation); this difference is also observed with other acidic and acid sensitive catchments in mid-Wales where $\mathrm{Ba}$ concentrations are either constant or increase with increasing flow. In contrast, $\mathrm{Ca}, \mathrm{Mg}$ and $\mathrm{Sr}$ tend to decline with increasing flow in line with their primary source in the bedrock (Neal et al., 1997a). It seems that $\mathrm{Ba}$ is cycling through the vegetation and that there is some biological mediation. However, there seems to be a clear separation in concentration with the felled site having concentrations typically twice that of the control. This links in some way to differences in the hydrogeochemistry, and as magnesium also shows distinct differences between the felling and control sites, it implies some difference in mineral types within the bedrock and different extents of weathering. The patterns of change are shown in the Appendix, Figs. A1 and A2.

3. $\mathrm{Br}$ and $\mathrm{I}$. The behaviour of these components is strongly related to biological processes; there is a strong seasonal pattern with concentrations highest in the summer and autumn when decomposition rates are highest (Appendix Fig. A2). Concentrations of both $\mathrm{Br}$ and I almost double in the year of felling; that of $\mathrm{Br}$ decreases gradually over the next three years while that of I remains high over the same period.

4. Gran alkalinity and ANC. Gran alkalinity and ANC are approximately equal in these waters (Appendix Fig. A4) as the additional components within the ANC (a positive term linked to DOC and a negative term linked to Al) are relatively low and effectively cancel out. Prior to felling, the felling site had a lower Gran alkalinity and ANC than the control. During this pre-felling period, there was a systematic variation in Gran alkalinity with highest values occurring during the summer period and a cyclical annual pattern of behaviour was observed. The difference in Gran alkalinity and ANC between the felling and control sites was particularly marked for the pre-felling period during the summer, where the values were about $150 \mu \mathrm{Eq} \mathrm{l}^{-1}$ higher for the control-site than the felled-site. However, during the winter months, prefell, this difference reduced to almost undetectable levels. Subsequent to felling, the same cyclical pattern was maintained for the felled-site. However, for the control site, the Gran alkalinity and ANC values were lower during the summer months for post-felling rather than pre-felling times: during the winter months, no difference in pattern occurred. Hence, the patterns of variation became almost identical for the control and felled-sites during the post-felling period. This means that the stream waters have become less acidic after felling by about $150 \mu \mathrm{Eq} \mathrm{l}^{-1}$, relative to the control, during the summer months. In terms of biological response, this difference is not significant as (a) the values remain for the most part above zero and (b) it is the control, rather than the felled-site that changes over time. 
5. Potassium is an important plant nutrient and is strongly bound to cation exchange sites in the soil. With felling, potassium will be released from the decaying vegetation for uptake into the soil (Goulding and Stevens, 1988) and the growing biomass (Fahey et al., 1991). At Vyrnwy, a sharp decrease in $\mathrm{K}$ concentrations during the summer months following harvesting probably reflects rapid uptake into the developing vegetation. There may be an additional release of $\mathrm{K}$ during the winter of 1997/98 at the time of felling, but the change in concentration is relatively small and of short duration.

The effects of catchment felling on stream water chemistry can be addressed in terms of flux differences over time between the felled and control sites (Neal, 2002a) using a methodology involving the creation of a daily chemical timeseries using the daily flow record to infill the weekly to fortnightly chemical data for each year. To do this, the chemical data were sorted according to flow and data infilling was achieved by calculating the average chemistry between the previous and next flow value with full chemistry. The estimates only can be classed as 'semiquantitative' as there is no clear means of correcting accurately for changes in the flow-concentration relationship due to the effects of felling on interception losses and runoff volume. The patterns observed are illustrated in Figs. 4a and $4 \mathrm{~b}$. The analysis shows that:

- $\mathrm{Na}$ and $\mathrm{Cl}$ fluxes increase at felling and then decrease. For $\mathrm{Cl}$, this appears to correspond to an initial release from storage within the catchment with the store becoming progressively depleted over about a year. The reduction in mist and aerosol capture due to removal of the tree canopy means that the flux difference between
NO3

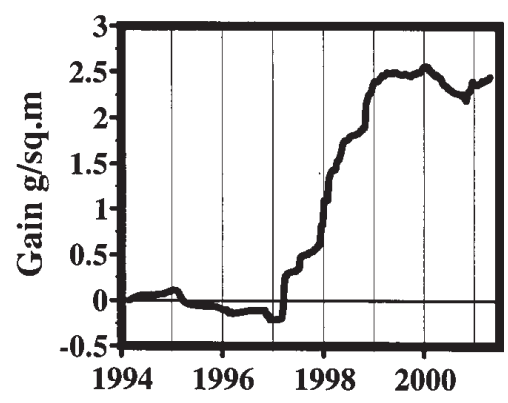

$\mathrm{Br}$

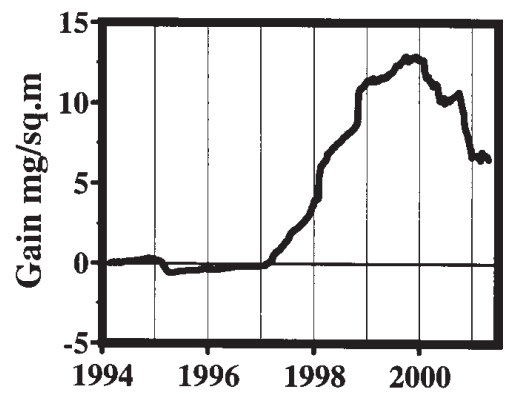

Alkalinity

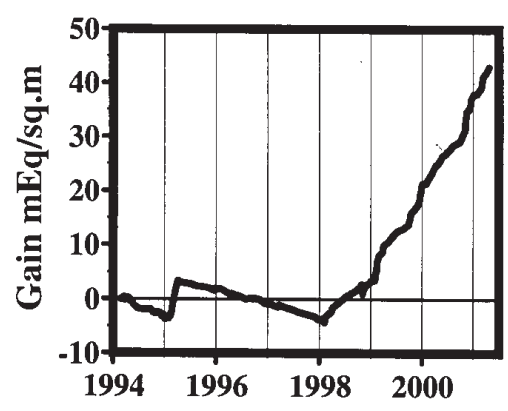

Cl
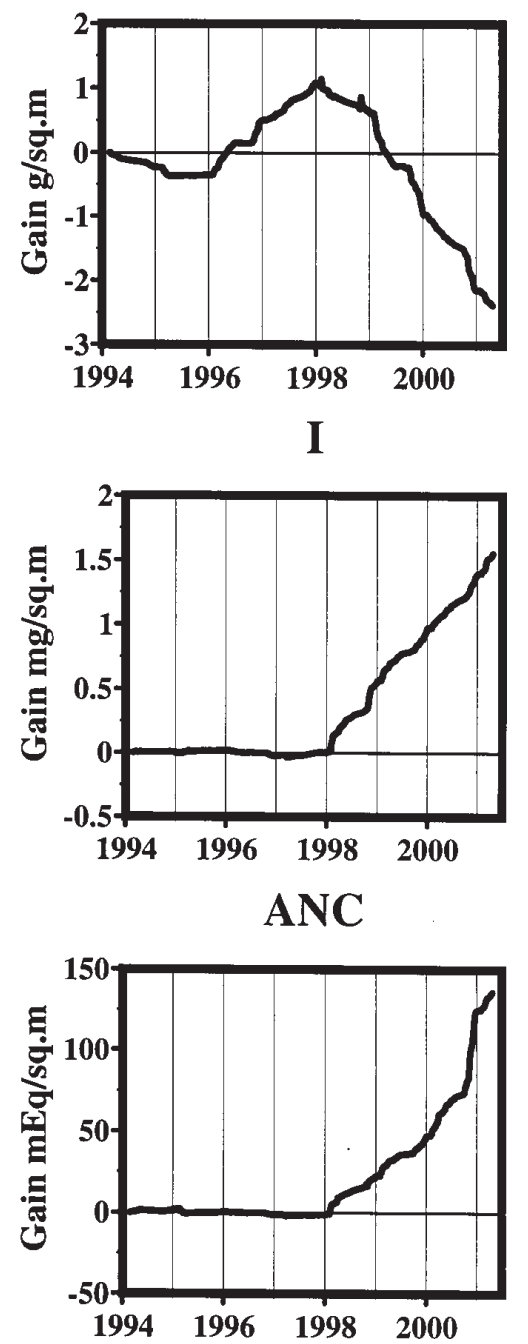

Fig. 4a. Cumulative flux difference time series for $\mathrm{NO}_{3}, \mathrm{Cl}, \mathrm{Br}, \mathrm{I}$, Gran alkalinity and ANC. 
Na
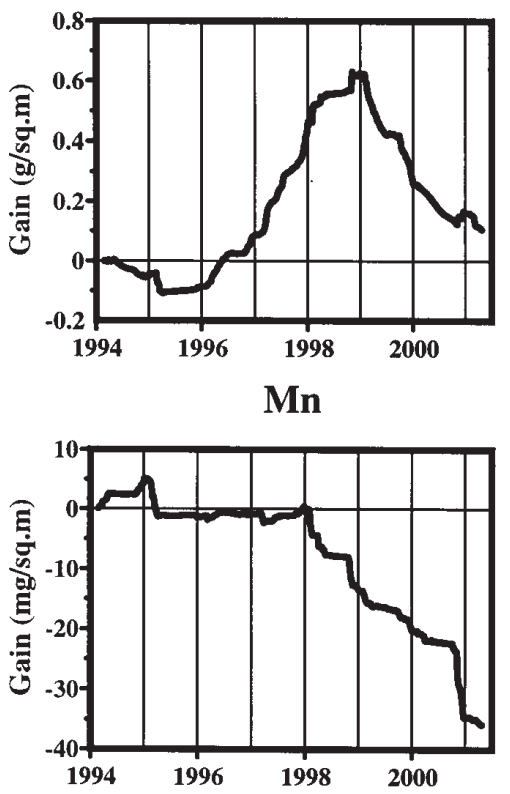

DOC
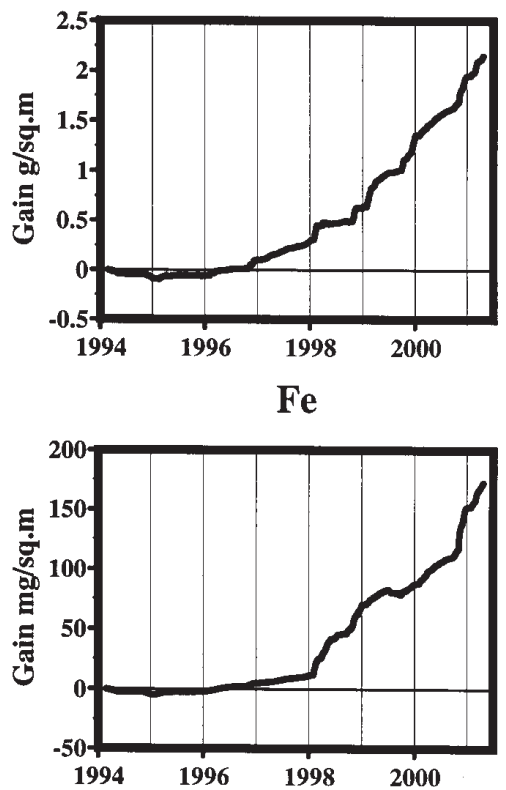

Fig. 4b. Cumulative flux difference time series for $\mathrm{Na}, \mathrm{Mn}, \mathrm{Fe}$ and $\mathrm{DOC}$.

the two sites after felling becomes negative. The case of $\mathrm{Na}$ is similar, but the subsequent flux reduction due to mist and aerosol capture is slowed down due to cation exchange reactions.

- Mn fluxes decrease after felling. The reason for this is not clear.

- $\mathrm{NO}_{3}$ and $\mathrm{Br}$ fluxes increase with felling, but the flux increase tails off within two years. A subsequent decline is expected as the new vegetation takes up more $\mathrm{NO}_{3}$ and $\mathrm{Br}$ into the growing biomass.

- Fluxes of Gran alkalinity, ANC, DOC, Fe and I all increase with felling. These higher fluxes have been maintained throughout the study period. The increases in DOC, Fe and I probably relate to the decomposition of felling residues (brash, fine roots etc.) and mineralisation of soil organic matter. Further work is required to determine the relative contributions from these sources. The increases in Gran alkalinity and ANC indicate a reduction in acidity. This links to the reduction in strong acid anion concentrations and to their influence as mobile anions on cation exchange reactions.

\section{Ground waters}

The ground waters are moderately acidic to moderately alkaline with the felled (VBH1) site having a lower $\mathrm{pH}$ (mean 6.0, range 5.4 to 6.6) than the control (VBH2; mean 7.0 , range 6.2 to 8.0). The alkalinities and ANC values are both positive and similar in size and range. The waters are of a calcium bicarbonate type typical of the weathered bedrock zones in the area (Neal et al., 1997b). The difference in $\mathrm{pH}$ between the sites reflects contrasting dissolved carbon dioxide partial pressures, which, for the felled site has a mean value of 54 times atmospheric pressure resulting from soil respiration and decomposition of soil organic carbon; this is typical of ground water in nearby areas. Degassing of carbon dioxide seems to have occurred at the control site such that excess carbon dioxide pressures have a mean value of four times atmospheric pressure.

As with the stream waters, the borehole chemical data are clearly correlated in terms of mean concentrations. Linear regression analysis shows that:

$$
\begin{aligned}
& \text { Groundwater }_{\text {control }}=0.82 \pm 0.15^{*} \text { Groundwater }_{\text {felling }}- \\
& 0.0 \pm 3.0 \\
& \mathrm{r}^{2}=0.752, \mathrm{~N}=40
\end{aligned}
$$

and

$$
\begin{gathered}
\log _{10}(\text { Groundwater } \\
0.98 \pm 0.07 * \log _{10}\left(\text { Groundwater }_{\text {fell }}\right)-0.2 \pm 0.7 \\
r^{2}=0.980, N=36
\end{gathered}
$$

However, for the ground waters, the correlations are less strong than for the streams because of significant differences in mean calcium and nitrate concentrations (Fig. 3b).

The concentrations of many determinands vary markedly over time with or without the influence of felling (Appendix 
A4 and A5). In the case of Mn and I, the rapid decline in the initial peak in concentration over the first few months is probably a result of the borehole installation. The largest changes occur for the weathering products (the divalent base cations, Gran alkalinity and ANC) with peaks during the summer months when dilution potentials are lowest. For these weathering products, the concentrations broadly increase with the ground water depth. The patterns are illustrated in Fig. 5 which shows:

1. The two boreholes have contrasting depths to the water table. For the felled-site, water levels are deeper than for the control site ( 3 to $9 \mathrm{~m}$ compared to 0 to $4 \mathrm{~m}$ ).

2. There seem to be two patterns for Gran alkalinity versus depth for the felled-site - moderately low (100 to 400 $\mu \mathrm{Eq} \mathrm{1}^{-1}$ ) but scattered Gran alkalinities shallower than $7 \mathrm{~m}$ and a straight line of negative gradient for depths greater than $7 \mathrm{~m}$.

3. For the control site, the Gran alkalinity increases gradually with depth, but in a curvilinear manner, with the sharpest increases occurring at greater depths.

This probably reflects three processes.

1. Greater depth corresponds to increasingly dry periods and to longer ground water residence time: increasing residence times increase the extent of weathering.

2. For shallower ground water depths, the recharge from the acidic base cation depleted soil waters increases; there will be an increasing volume of storage/ground water flow and the residence times are lower. This feature will lead to a dilution in the concentration of the weathering products.

3. The differences in ground water level and contrasts in Gran alkalinity link to the hydrological processes. The interception of the ground water by the boreholes is linked to the positions of the major fractures. The erratic nature of the ground water system as observed elsewhere in the region and the salient hydrogeological and hydrogeochemical behaviours are difficult to quantify (Hill and Neal, 1997; Neal et al., 1997b,c).

The sea salts ( $\mathrm{Na}$ and $\mathrm{Cl}$ ) change relatively little, but on one occasion the concentrations were more than double. Correspondingly, the trends found for DOC and Fe in the streams was not observed in the ground waters.

The changes in response after felling correspond to the processes described for the streams and they are:

- $\mathrm{Na}$ and $\mathrm{Cl}$ concentrations increase with felling, initially; thereafter, concentrations decline to levels lower than those prior to felling.

- $\mathrm{NO}_{3}$ concentration peaks early in 1998 , following felling, but this is short lived and subsequently concentrations decline to levels lower than those prior to felling.

- $\mathrm{Ca}, \mathrm{Gran}$ alkalinity and ANC concentrations are higher for the control than for the felled site. However, concentrations become very similar following felling. This change corresponds to a lowering of concentrations for the control borehole rather than an increase in that for the felled site.

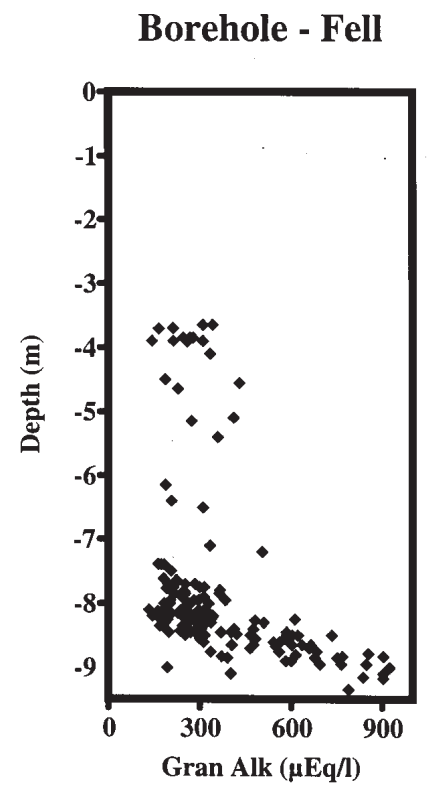

\section{Borehole - control}

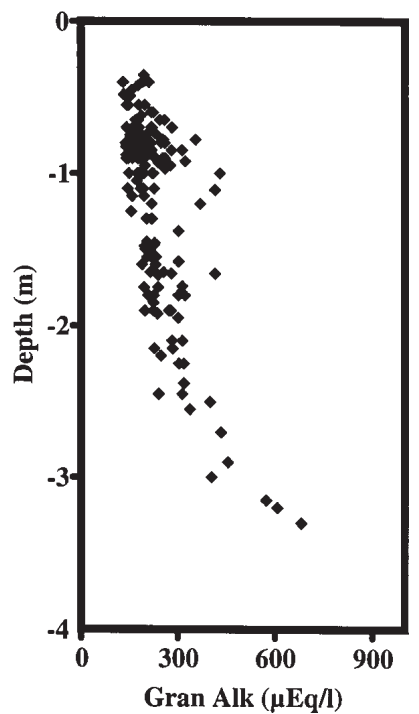

Fig. 5. The relationship between Gran alkalinity and depth for boreholes 1 and 2: monitoring period October 1994 to February 2001. 
- $\mathrm{Mg}$ concentrations mirror those for $\mathrm{Ca}$, Gran alkalinity and $\mathrm{ANC}$, reflecting the greater importance of weathering sources for $\mathrm{Mg}$ compared to the streams $(\mathrm{Mg}$ concentrations are about double those in the streams).

\section{THERMODYNAMIC ANALYSIS}

The thermodynamic analysis features links to both aluminium speciation and mineral saturation levels. These features are described separately below and summary statistics are provided in Table 3.

\section{Aluminium speciation}

The relative proportions of the complexed and uncomplexed aluminium species are highly variable in both the stream and ground waters. The main features are as follows.

- The dominant form of aluminium is as hydroxyl bound species with proportions varying between 20 and 95\%. In general, the percentage of hydroxyl bound aluminium increases with increasing $\mathrm{pH}$.

- Aluminium is significantly complexed to fluoride and the proportion of fluoride bound aluminium varies between 3 and 64\%. The percentage fluoride-bound aluminium decreases with increasing $\mathrm{pH}$ and this links to the increasing competitiveness of hydroxide ions for binding with aluminium as $\mathrm{pH}$ increases.

- There is significant binding of aluminium with organic matter, the extent of variation being 0 to $59 \%$. This binding is very variable with $\mathrm{pH}$ and no clear pattern emerges.

- There is some binding of aluminium with silicon (0 to $16 \%$ ), and there is no clear variation with $\mathrm{pH}$.

- Trivalent aluminium is barely significant (less than 4\%) due to the relatively high pHs encountered. Trivalent aluminium concentrations decrease with increasing $\mathrm{pH}$.

These results are very similar to those presented by Neal (1995) for streams in mid-Wales.

\section{Aluminium solubility controls}

The waters vary in their degrees of mineral saturation with respect to crystalline to amorphous forms of aluminium hydroxide (synthetic gibbsite, natural gibbsite, microcrystalline gibbsite and amorphous $\left.\mathrm{Al}(\mathrm{OH})_{3}\right)$ and minerals such as kaolinite, haloysite, imogolite and jurbanite and, clearly, no equilibrium solubility control is operative. For example, in the case of aluminium hydroxide, the saturation level varies for stream and ground waters by over two units and the waters go from undersaturated to saturated

Table 3. Aluminium speciation and solubility data for Vyrnwy streams and ground waters. The data covers the monitoring period October 1994 to February 2001.

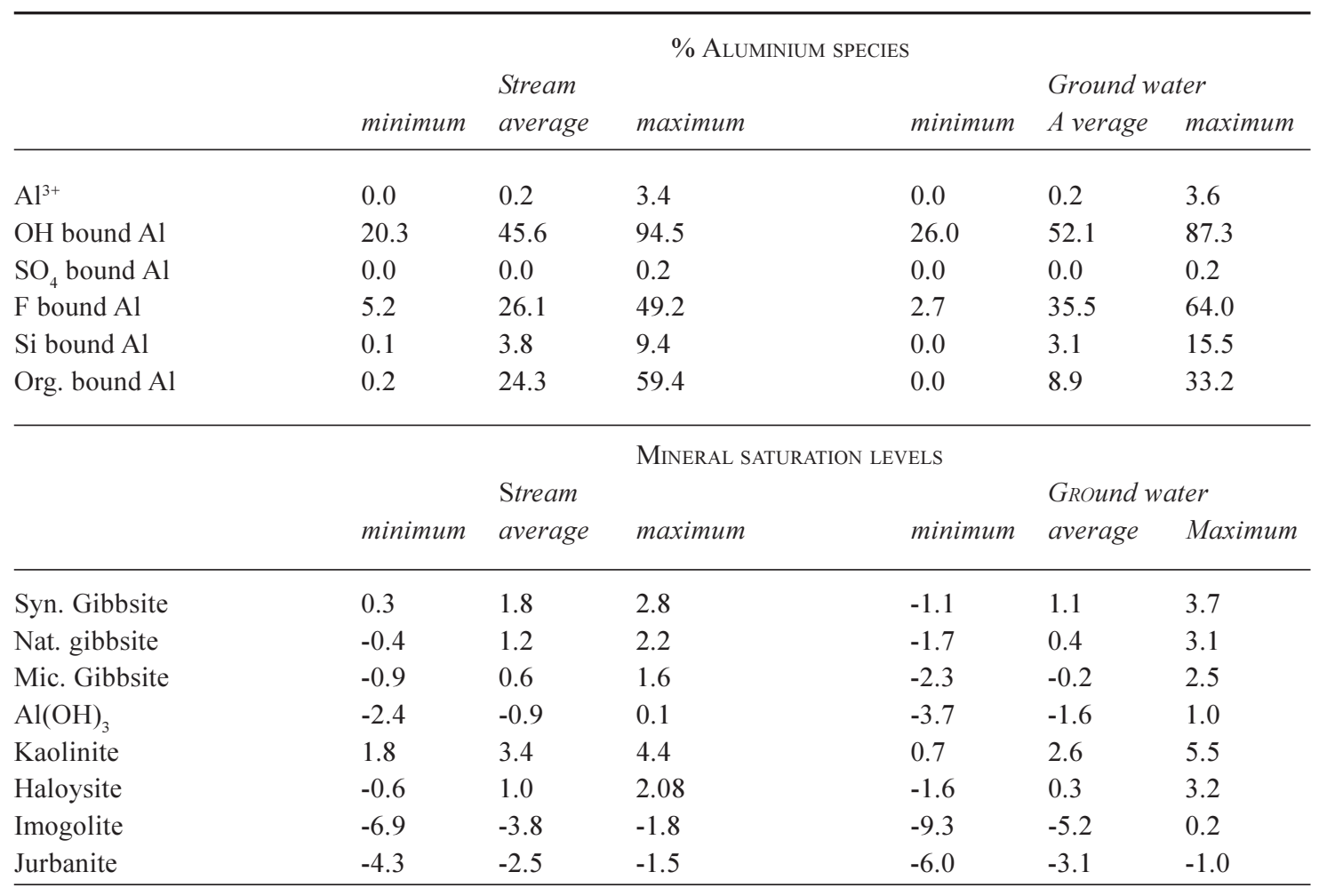


(amorphous $\mathrm{AL}(\mathrm{OH})_{3}$ ), to undersaturated to oversaturated (microcrystalline and natural gibbsite) and from oversaturated to even more oversaturated (synthetic gibbsite) according to the extent of the crystallinity of the gibbsite involved (aluminium hydroxide solubility increases with increasing disorder within the crystal lattice).

The change in degree of saturation is linked to the $\mathrm{pH}$ of the solution and the extent of saturation increases linearly with increasing $\mathrm{pH}$. For example, linear regression analysis for the combined-stream and combined-ground waters reveals

$$
\begin{gathered}
\text { Sat }_{\text {micro crystalline gibbsite }}=1.00 \pm 0.08 * \mathrm{pH}-5.89 \pm 0.47 \\
\mathrm{r}^{2}=0.685, \mathrm{~N}=300
\end{gathered}
$$

for the stream waters and,

$$
\begin{gathered}
\text { Sat }_{\text {micro crystalline gibbsite }}=1.68 \pm 0.08 * \mathrm{pH}-11.1 \pm 1.0 \\
\mathrm{r}^{2}=0.786, \mathrm{~N}=318
\end{gathered}
$$

for the ground waters.

This feature indicates that aluminium hydroxide solubility controls are not operative because (a) there is not a constant degree of saturation and (b) for an equilibrium solubility control, the degree of saturation should be independent of $\mathrm{pH}$ even though the extent of saturation is estimated from the $\mathrm{pH}$. Table 3 shows that none of the common minerals associated with aluminium solubility controls in acidic waters is operative. These findings agree with earlier thermodynamic studies in the Welsh region (Neal et al., 1989, 1990).

\section{Discussion}

The water quality variations encountered within the Vyrnwy catchments are similar to those for other acidic and acid sensitive upland areas of the UK (e.g. the Plynlimon catchments of the Hafren forest in mid-Wales; Neal et al., 1997a, 2001; Beddgelert forest in north Wales; Stevens and Hornung 1988; Kershope forest in northern England; Adamson et al., 1987; Stevens et al., 1988). The salient features are as follows.

- Rainfall is moderately acidic and comprises two main components, sea salts derived from the Irish Sea and the Atlantic Ocean, and pollutants originating from industrial areas of the UK, from Europe and even further afield (Wilkinson et al., 1997). In terms of major ions, the rainfall chemistry at Vyrnwy is very similar to that at Plynlimon (Table 4; Wilkinson et al., 1997; Neal et al., 1997a) and is consistent with more spatially extensive data from across Wales (Reynolds et al., 1999). Compared to that at Plynlimon, rainfall at Vyrnwy is moderately more polluted in respect of $\mathrm{Cl}$, $\mathrm{SO}_{4}, \mathrm{NO}_{3}, \mathrm{DOC}$ and several of the trace elements (Al, $\mathrm{Cr}, \mathrm{Cu}, \mathrm{Fe}, \mathrm{Mo}, \mathrm{Ni}, \mathrm{Pb}$ and $\mathrm{Zn}$ ). This may reflect the

\begin{tabular}{|c|c|c|c|c|c|c|c|}
\hline & & Vyrnwy & Plynlimon & & & Vyrnwy & Plynlimon \\
\hline $\mathrm{Na}$ & $\mathrm{mg} \mathrm{l}^{-1}$ & 1.93 & 2.30 & $\mathrm{Al}$ & $\mu \mathrm{g} \mathrm{l}^{-1}$ & 16 & 6.22 \\
\hline K & $\mathrm{mg} \mathrm{l}^{-1}$ & 0.29 & 0.12 & B & $\mu \mathrm{g} \mathrm{l}^{-1}$ & 3.3 & 3.16 \\
\hline $\mathrm{Ca}$ & $\mathrm{mg} \mathrm{l}^{-1}$ & 0.82 & 0.19 & $\mathrm{Ba}$ & $\mu \mathrm{g} \mathrm{l}^{-1}$ & 1.8 & 4.92 \\
\hline $\mathrm{Mg}$ & $\mathrm{mg} \mathrm{l}^{-1}$ & 0.32 & 0.28 & $\mathrm{Be}$ & $\mu \mathrm{g} \mathrm{l}^{-1}$ & 0 & 0.01 \\
\hline $\mathrm{NH}_{4}$ & $\mathrm{Mg}-\mathrm{NH}_{4} \mathrm{l}^{-1}$ & 0.88 & 0.29 & $\mathrm{Br}$ & $\mu \mathrm{g}^{-1}$ & 11.8 & 16.36 \\
\hline $\mathrm{Cl}^{+}$ & $\mathrm{mg} \mathrm{l}^{-1}$ & 4.26 & 4.33 & Co & $\mu \mathrm{g} \mathrm{l}^{-1}$ & 0.1 & 0.04 \\
\hline $\mathrm{SO}_{4}$ & $\mathrm{Mg}-\mathrm{SO}_{4} \mathrm{l}^{-1}$ & 2.12 & 1.57 & $\mathrm{Cr}$ & $\mu \mathrm{g}^{-1}$ & 3.9 & 1.66 \\
\hline $\mathrm{NO}_{3}$ & $\mathrm{Mg}-\mathrm{NO}_{3} \mathrm{l}^{-1}$ & 2.27 & 0.77 & $\mathrm{Cu}$ & $\mu \mathrm{g} \mathrm{l}^{-1}$ & 2.8 & 1.47 \\
\hline $\mathrm{PO}_{4}$ & $\mathrm{mg}-\mathrm{P}^{-1}$ & 0.03 & 0.02 & $\mathrm{Fe}$ & $\mu \mathrm{g}^{-1}$ & 19.8 & 5.78 \\
\hline $\mathrm{F}$ & $\mathrm{mg} \mathrm{l}^{-1}$ & 0.02 & 0.02 & I & $\mu \mathrm{g} \mathrm{l}^{-1}$ & 1.1 & 1.16 \\
\hline DOC & $\mathrm{mg} \mathrm{l}^{-1}$ & 1.09 & 0.48 & $\mathrm{Li}$ & $\mu \mathrm{g} \mathrm{l}^{-1}$ & 0.1 & 0.08 \\
\hline \multirow[t]{2}{*}{$\mathrm{Si}$} & $\mathrm{mg} \mathrm{l}^{-1}$ & 0.1 & 0.1 & $\mathrm{Mn}$ & $\mu \mathrm{g}^{-1}$ & 5.7 & 1.06 \\
\hline & & & & $\mathrm{Ni}$ & $\mu \mathrm{g}^{-1}$ & 1.5 & 0.46 \\
\hline $\mathrm{pH}$ & & 5.34 & 4.99 & $\mathrm{~Pb}$ & $\mu \mathrm{g}^{-1}$ & 92 & 13.73 \\
\hline \multirow[t]{3}{*}{ G. Alk } & $\mu \mathrm{Eq}^{-1}$ & 41 & 13 & $\mathrm{Sr}$ & $\mu \mathrm{g}^{-1}$ & 2.8 & 2 \\
\hline & & & & $\mathrm{Y}$ & $\mu \mathrm{g} \mathrm{l}^{-1}$ & 0 & 0 \\
\hline & & & & $\mathrm{Zn}$ & $\mu \mathrm{g}^{-1}$ & 19.4 & 8.59 \\
\hline
\end{tabular}
closer proximity of the Vyrnwy site to the industrial centres of the Wirral and north-western England.

Table 4. A comparison of rainfall averages for Vyrnwy and Plynlimon. 
- On passage to the stream, the rainfall becomes less acidic due to weathering reactions within the soil and ground water zones. The streams show contrasting behaviour under baseflow and stormflow conditions due to the dominant input, respectively, of shallow ground waters where weathering predominates and to more acidic soil waters where hydrolysable trace metals are mobilised. Due to the mobilisation of metals within the soils, stormflow waters are enriched in $\mathrm{Al}, \mathrm{Ba}, \mathrm{Fe}$ and $\mathrm{Mn}$. Correspondingly, the weathering of the bedrock leads to the generation of $\mathrm{Ca}, \mathrm{Mg}$ and $\mathrm{Si}$. Concentrations of $\mathrm{Na}, \mathrm{Cl}$ and $\mathrm{SO}_{4}$ are higher in runoff than rainfall due to evaporative concentration of the rainfall as well as scavenging of cloud water droplets and aerosols by the forest canopy.

- Ground water has the highest base cation concentrations and the lowest acidity. This corresponds to the low flow end member of the streams: i.e. waters that experience the highest degree of weathering interactions with the bedrock.

- There is no evidence of equilibrium solubility controls for any of the minerals commonly associated with such controls in acidic and acid sensitive systems.

- Forest harvesting results in major changes in the biogeochemical functioning of the soil and its interaction with the vegetation. Initially, nitrate is released due to increased breakdown of organic matter and a reduction in plant uptake. Nitrate concentrations subsequently decline because of uptake by the newly developing ground vegetation. Indeed, nitrate concentrations after felling are lower than when the trees were standing. There are several reasons for this. Firstly, the trees at Vyrnwy were 34 years old when felled, which is just beyond the age threshold at which nitrate leaching increases with stand age in Welsh forests due to the interaction between stand age and atmospheric nitrogen deposition (Emmett et al. 1993; Stevens et al., 1994). The mean nitrate concentration in the Vyrnwy control stream $\left(2.0 \mathrm{mg} \mathrm{l}^{-1} \mathrm{NO}_{3}\right)$ is closely matched to the mean value from streams draining five stands of Sitka spruce aged 30-45 years sampled across north and mid-Wales in 1991 (2.05 $\mathrm{mg} \mathrm{l}^{-1} \mathrm{NO}_{3}$; Hughes et al., 1994). In contrast, the mean value for five moorland streams sampled in the same study was $0.5 \mathrm{mg} \mathrm{l}^{-1} \mathrm{NO}_{3}$ (Hughes et al., 1994). Thus, lower nitrate concentrations would be anticipated in the felled stream, once the initial nitrate pulse has passed, simply because the mature forest system, which was leaching nitrate, has been removed. Furthermore, it is likely that rapid re-vegetation of the site will further reduce nitrate leaching. Studies at Beddgelert forest in north Wales have shown that nitrogen is incorporated in the growing biomass of the ground flora and Sitka spruce seedlings planted within a year of clear felling (Stevens and Hornung, 1990; Emmett et al., 1991). Similar declines in nitrate concentrations have been observed for streams in the Plynlimon area (Neal, 2002a,b; Neal et al., 2003).

- Felling results in reduced evapotranspiration losses and reduced scavenging of cloud water droplets and aerosols from the atmosphere. Because of this, the concentrations of $\mathrm{Na}$ and $\mathrm{Cl}$ after felling are lower than before. However, a small increase in $\mathrm{Na}$ and $\mathrm{Cl}$ concentrations around the time of felling implies that there is some form of initial release of these components. This is most clearly observed when cumulative flux differences are considered. In the case of $\mathrm{Na}$, such an increase would be anticipated due to the initial increase in the strong acid anion concentrations $\left(\mathrm{Cl}+\mathrm{SO}_{4}+\mathrm{NO}_{3}\right)$ affecting the cation exchange equilibrium in which $\mathrm{Na}$ is involved (Neal, 2002a). However, an initial increase in $\mathrm{Cl}$ would not be anticipated as this determinand is commonly considered to (a) come mainly from atmospheric sources and (b) be chemically unreactive. Indeed, the results differ from a felling study in mid-Wales, where no initial chloride release occurred prior to the subsequent decline in $\mathrm{Cl}$ flux (Neal, 2002a). This implies that, for brown podzolic soils, some storage term for $\mathrm{Na}$ and $\mathrm{Cl}$ seems to be affected during the initial stages of felling.

- The rapid decline in the $\mathrm{NO}_{3}$ felling pulse, coupled with the subsequent reduction in the strong acid anions following felling, results in a rapid decrease in stream water acidity which agrees with both theory and observation (Neal, 2002a,b).

In terms of the water quality issues linked with felling practices, the study indicates that there is no clear environmental issue for forestry on brown podzolic soils in the context of short lived responses to felling, as the $\mathrm{NO}_{3}$ peak is short lived. Overall, felling reduces stream acidity which is beneficial to stream ecology. This is good news for forest management, and endorses the proactive approaches being taken by organisations such as the Forestry Commission and Forest Enterprise (Neal and Reynolds, 1998a,b; Neal et al., 1998a,b).

\section{Wider comment}

This work completes, with other contributions in this special issue, the research on the impacts of forestry with felling in mid-Wales. As with the related studies, the work reinforces the benefits of proactive forest management and indicates that there may well be no major issues of felling other than 
those associated with particularly acid sensitive or particularly ecologically vulnerable areas. Nonetheless, it must be remembered that there remain longer term effects associated with export of base cations from the exported tree biomass and the potential acidification of the soils if the source of cation uptake into the next generation of forest is from the soil exchange store. This is linked to issues of forest sustainability which requires new research to settle such issues.

\section{References}

Adamson, J.K., Hornung, M., Pyatt, D.G. and Anderson, A.R., 1987. Changes in solute chemistry of drainage waters following clear felling of a Sitka spruce plantation. Forestry, 60, 165177.

Emmett, B.A., Anderson, J.M. and Hornung, M., 1991. Nitrogen sinks following two intensities of harvesting in a Sitka spruce forest (N. Wales) and the effect on the establishment of the next crop. Forest Ecol. Manage., 41, 81-93.

Emmett, B.A., Reynolds, B., Stevens, P.A., Norris, D.A., Hughes, S., Gorres, J. and Lubrecht, I., 1993. Nitrate leaching from afforested Welsh catchments - interactions between stand age and nitrogen deposition. Ambio, 22, 386-394.

Fahey, T.J., Hill, M.O., Stevens, P.A., Hornung, M. and Rowland, A.P., 1991. Nutrient accumulation in vegetation following conventional and whole-tree harvest of Sitka spruce plantations in North Wales. Forestry, 64, 271-288.

Freeman, C., Evans, C.D., Monteith, D.T., Reynolds, B. and Fenner, N., 2001. Export of organic carbon from peat soils. Nature, 412, 785.

Good, J.E.G. and Reynolds, B., 2001. The environmental effects of plantation forestry as exemplified by Sitka spruce in Wales. In: Tree Crop Ecosystems (Ecosystems of the World, Vol. 19), F.T. Last (Ed.) Elsevier, Amsterdam, The Netherlands. 193-216.

Goulding, K.W.T. and Stevens, P.A., 1988. Potassium reserves in a forested, acid upland soil and the effect on them of clear felling versus whole tree harvesting. Soil Use Manage., 4, 45-51.

Hill, T. and Neal, C., 1997. Spatial and temporal variation in $\mathrm{pH}$, Gran alkalinity and conductivity in surface runoff and ground water for the Upper River Severn catchment. Hydrol. Earth Syst. Sci., 1, 697-716.

Hughes, S., Reynolds, B. and Roberts, J.D., 1990. The influence of land management on concentrations of organic carbon and its effects on the mobilisation of aluminium and iron in podzol soils in Mid-Wales. Soil Use Manage., 6, 137-144.

Hughes, S., Reynolds, B., Brittain, S.A., Hudson, J.A. and Freeman, C., 1998. Temporal trends in bromide release from a drained gully mire. Soil Use Manage., 14, 248-250.

Mackie, A.H., 1987. The geology of the Llyn Brianne area, central Wales. Unpublished PhD Thesis, University of Cambridge, UK. 250pp.

Monteith, D.T. and Evans, C.D., 2000. UK Acid Waters Monitoring Network: 10 Year Report. ENSIS Publishing, London, UK. $364 \mathrm{pp}$.

National Assembly for Wales 2000. Woodlands for Wales. The National Assembly for Wales Strategy for Trees and Woodlands, National Assembly for Wales, Cardiff, UK. 49pp.

Neal, C., 1995. Aluminium speciation variations in an acidic upland stream draining the Hafren spruce forest, Plynlimon, Mid-Wales. J. Hydrol., 164, 39-51.
Neal, C., 2002a. Assessing environmental impacts on stream water quality: the use of cumulative flux and cumulative flux difference approaches to deforestation of the Hafren Forest, midWales. Hydrol. Earth Syst. Sci., 6, 421-432.

Neal, C., 2002b. Nutrient concentrations and fluxes for podzolic and gley soils at Plynlimon, mid-Wales: implications for modelling inorganic nitrogen and phosphorus in upland UK environments. Hydrol. Earth Syst. Sci., 6, 403-420.

Neal, C., 2003. Dissolved beryllium in rainfall, stream and shallow ground waters in the Upper River Severn catchments, Plynlimon, mid-Wales. Sci. Total Envir, In press.

Neal, C. and Christophersen, N., 1989. Inorganic aluminiumhydrogen relationships for acidified streams: the role of water mixing processes. Sci. Total Envir., 80, 195-203.

Neal, C. and Reynolds, B., 1998a. The impact of conifer harvesting and replanting on upland water quality. Research and development technical report P211 to the Environment Agency, UK. Environment Agency, Rivers House, Waterside Drive, Aztec West, Almondsbury, Bristol, BS32 4UD, UK. 137pp.

Neal, C. and Reynolds, B., 1998b. The impact of conifer harvesting and replanting on upland water quality. Research and development project record to the Environment Agency. P2/ 067/1, Main Text, 121pp. P2/067/2, Figures, Tables and Appendices, 102pp. P2/067/3, Compendium of water quality time-series, 84pp. Environment Agency, Rivers House, Waterside Drive, Aztec West, Almondsbury, Bristol, BS32 4UD, UK.

Neal, C., Reynolds, B., Stevens, P. and Hornung, M., 1989. Hydrogeochemical controls for inorganic aluminium in acidic stream and soil waters at two upland catchments in Wales. $J$. Hydrol., 106, 155-175.

Neal, C., Reynolds, B., Stevens, P.A., Hornung, M. and Brown, S.J., 1990. Dissolved inorganic aluminium in acidic stream and soil waters in Wales. In: Acid Waters in Wales, R.W. Edwards, A.S. Gee and J.H. Stoner (Eds.). Kluwer, Dordrecht, The Netherlands. 173-188.

Neal, C., Smith, C.J., Jeffery, H.A., Harrow, M.L. and Neal, M., 1996. Dissolved chromium pollution in rainfall and surface waters in Mid-Wales during the mid 1980s. Sci. Total Envir., 188, $127-138$.

Neal, C., Wilkinson, J., Neal, M., Harrow, M., Wickham, H., Hill, L. and Morfitt, C., 1997a. The hydrochemistry of the River Severn, Plynlimon, mid-Wales. Hydrol. Earth Syst. Sci., 1, 583618.

Neal, C., Robson, A.J., Shand, P., Edmunds, W.M., Dixon, A.J., Buckley, D.K., Hill, S., Harrow. M., Neal, M. and Reynolds, B., 1997b. The occurrence of ground water in the lower Palaeozoic rocks of upland Central Wales. Hydrol. Earth Syst. Sci., 1, 3-18.

Neal, C., Hill, T., Hill, S. and Reynolds, B., 1997c. Acid neutralization capacity measurements in surface and ground waters in the Upper River Severn, Plynlimon: from hydrograph splitting to water flow pathways. Hydrol. Earth Syst. Sci., 1, 687-696.

Neal, C., House, W.A. and Down, K., 1998a. An assessment of excess carbon dioxide partial pressures in natural waters based on pH and Gran alkalinity measurements. Sci. Total Envir., 210/ 211, 187-204.

Neal, C., Reynolds, B., Adamson, J.K., Stevens, P.A., Neal, M., Harrow, M.L. and Hill, S., 1998b. Analysis of the impacts of major anion variations on surface water acidity: case studies from Wales and Northern England. Hydrol. Earth Syst. Sci., 2, 303-322. 
Neal, C., Reynolds, B., Wilkinson, R.J., Hill, T., Neal, M., Hill, S. and Harrow, M.L., 1998c. The impacts of conifer harvesting on runoff water quality: a regional survey for Wales. Hydrol. Earth Syst. Sci., 2, 323-344.

Neal, C., Neal, M., Wickham, H. and Harrow, M., 2000. The water quality of a tributary of the Thames, the Pang, southern England. Sci. Total Envir., 251/252, 459-476.

Neal, C., Reynolds, B., Neal, M., Pugh, B., Hill, L. and Wickham, H., 2001. Long term changes in the water quality of rainfall, cloud-water and stream water for moorland, forested and clearfelled catchments at Plynlimon, mid-Wales. Hydrol. Earth Syst. Sci., 5, 459-476.

Neal, C., Reynolds, B., Neal, M., Hill, L., Wickham, H. and Pugh, B., 2003. Nitrogen in rainfall, cloud water, throughfall, stemflow, stream water and ground water for the Plynlimon catchments of mid-Wales. Sci. Total Envir., 121-152.

Neal, C., Reynolds, B., Neal, M., Wickham, H., Hill, L. and Williams, B., 2004a. The water quality of streams draining a plantation forest on gley soils: the Nant Tanllwyth, Plynlimon mid-Wales. Hydrol. Earth Syst. Sci., 8, 485-502.

Neal, C., Reynolds, B., Neal, M., Wickham, H., Hill, L. and Williams, B., 2004b. The impact of conifer harvesting on stream water quality: the Afon Hafren, mid-Wales. Hydrol. Earth Syst. Sci., 8, 503-520.

Reynolds, B., Lowe, J.A.H., Smith, R.I., Norris, D.A., Fowler, D., Bell, S.A., Stevens, P.A. and Ormerod, S.J., 1999. Acid deposition in Wales: the results of the 1995 Welsh Acid Waters Survey. Envir. Pollut., 105, 251-266.

Reynolds, B, Stevens, P.A., Brittain, S.A., Norris, D.A., Hughes, S. and Woods, C., 2004. Long-term changes in precipitation and stream water chemistry in small forest and moorland catchments at Beddgelert Forest, north Wales. Hydrol. Earth Syst. Sci., 8, 436-448.
Schecher, W.D. and Driscoll, C.T., 1988. An evaluation of the equilibrium calculations within acidification models. The effects of uncertainty in measured chemical components. Water Resour. Res., 24, 533-540.

Stevens, P.A. and Hornung, M., 1988. Nitrate leaching from a felled Sitka spruce plantation in Beddgelert forest, North Wales. Soil Use Manage., 4, 3-9.

Stevens, P.A. and Hornung, M., 1990. Effects of forest harvesting and ground flora re-establishment on inorganic-N leaching from a Sitka spruce plantation in north Wales, UK. Biogeochemistry, $10,53-65$.

Stevens, P.A., Adamson, J.K., Anderson, M.A. and Hornung, M. 1988. Effects of clear felling on surface water quality and site nutrient status. In: Ecological Change in the Uplands, M.B. Usher and D.B.A. Thompson (Eds.), British Ecological Society Special Publication no. 7, Blackwell, Oxford, UK. 289-294.

Stevens, P.A., Norris, D.A., Sparks, T.H. and Hodgson, A.L., 1994 The impacts of atmospheric $\mathrm{N}$ inputs on throughfall, soil and stream water interactions for different aged forest and moorland catchments in Wales. Water Air Soil Pollut., 73, 297-317.

UK Government 1994. Sustainable Forestry: the UK Programme, HMSO, London, UK.

Wilkinson, J., Reynolds, B., Neal, C., Hill, S., Neal, M. and Harrow, M., 1997. Major, minor and trace element composition of mist and rainwater at Plynlimon, mid-Wales. Hydrol. Earth Syst. Sci. 1, 557-570. 
Appendix

$\mathrm{Na}$
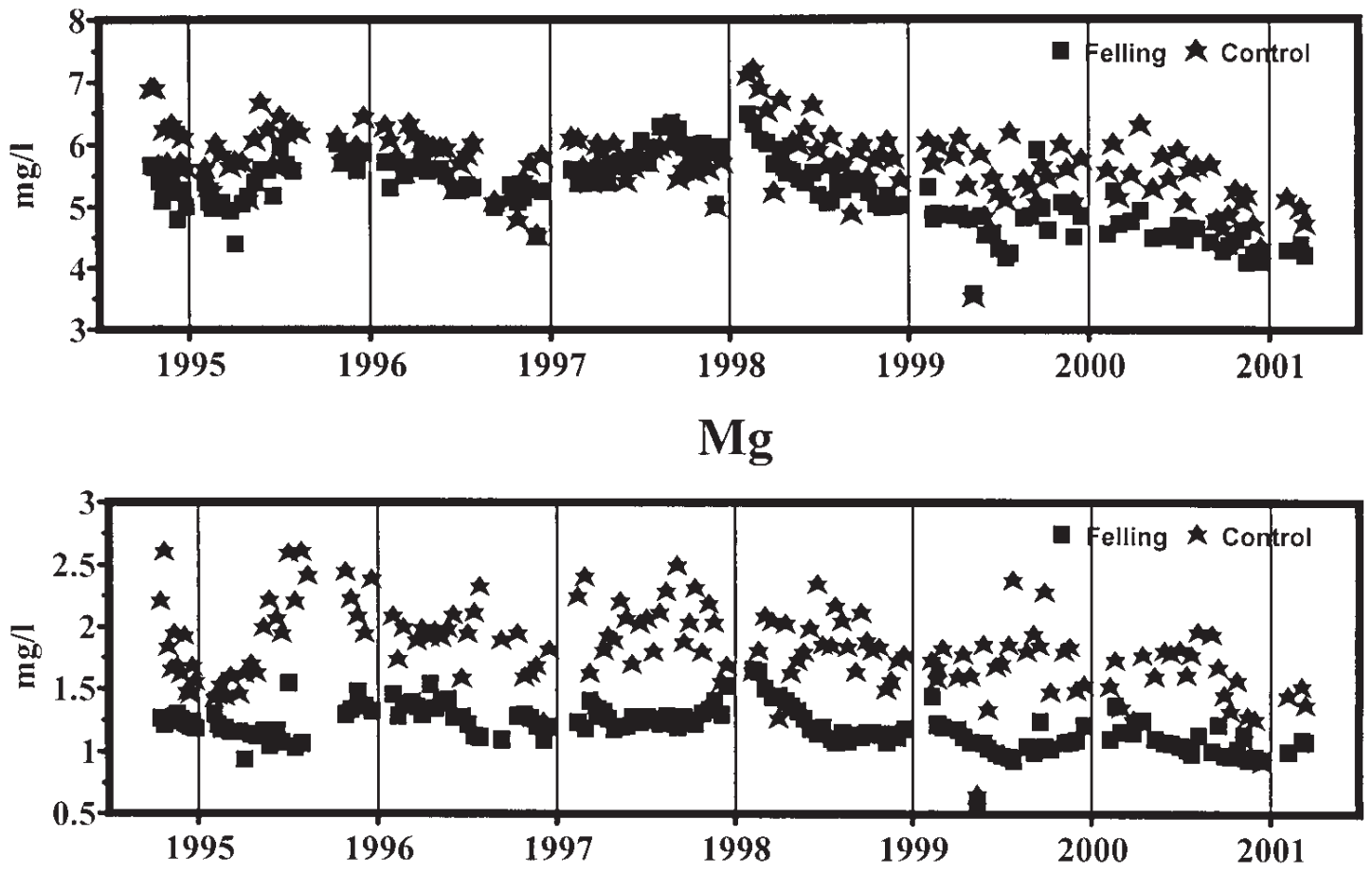

K
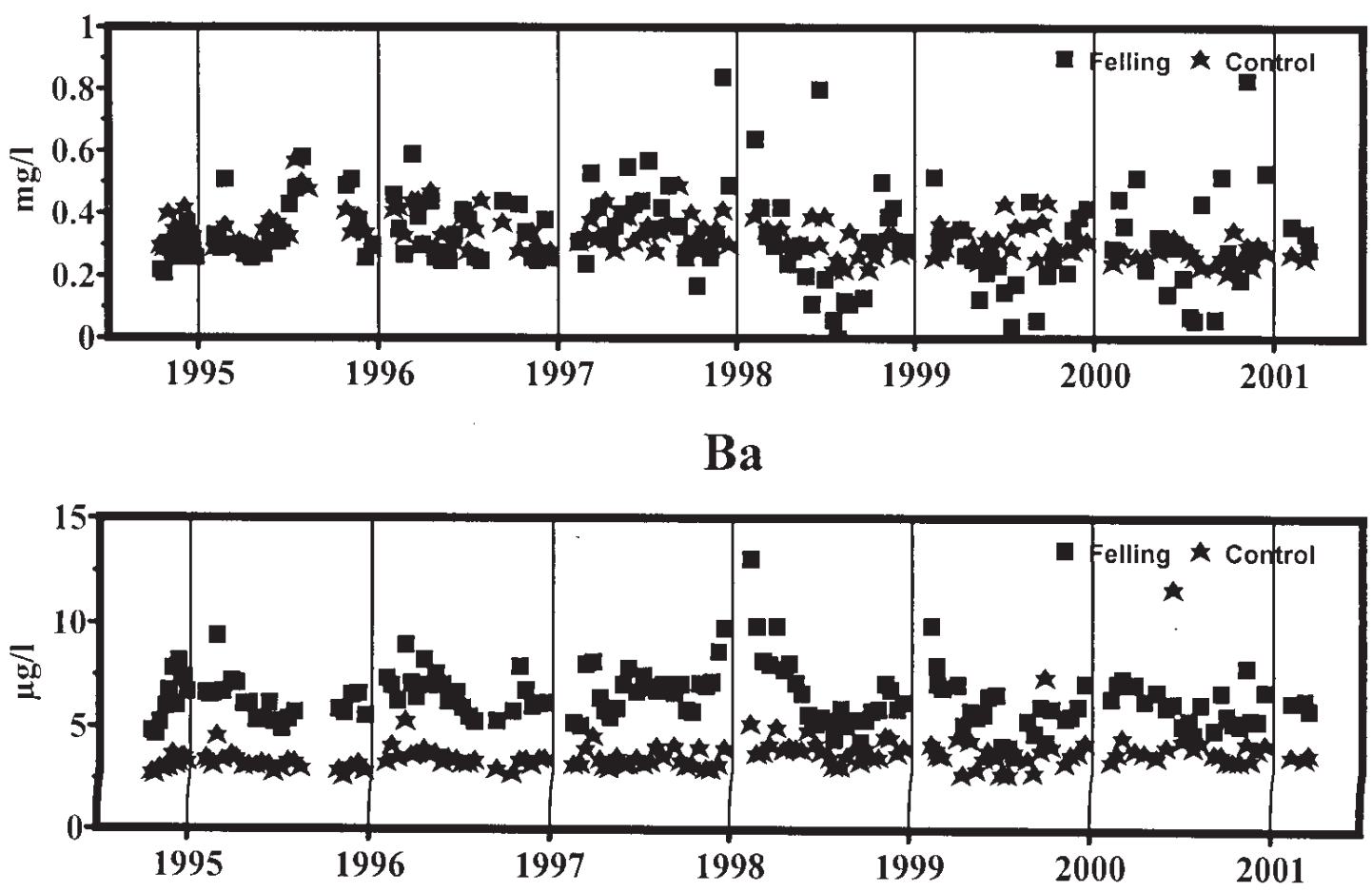

Fig. A1. Time series for $\mathrm{Na}, \mathrm{Mg}, \mathrm{K}$ and Ba concentrations for felling and control stream sites. 
NO3
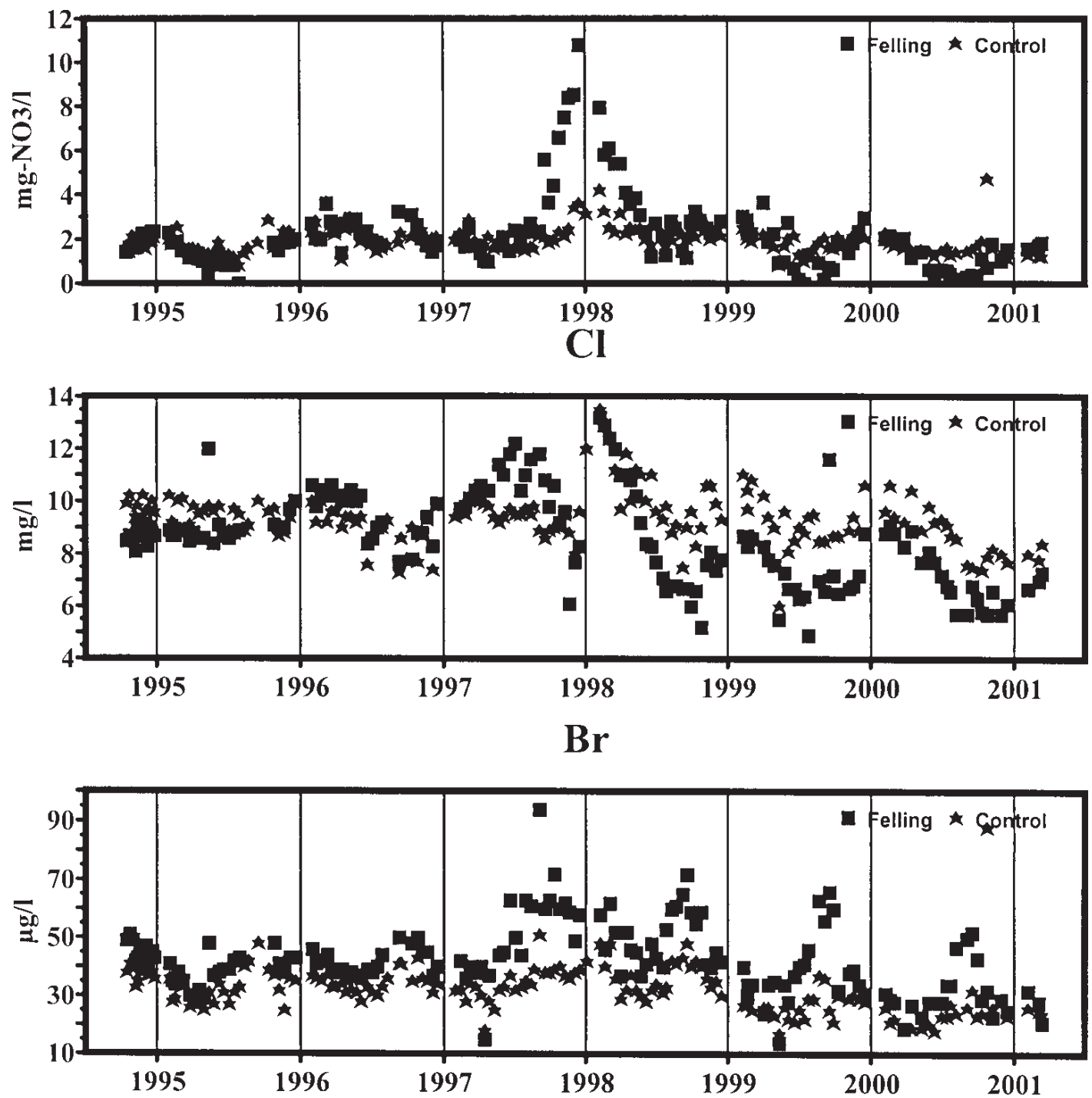

I

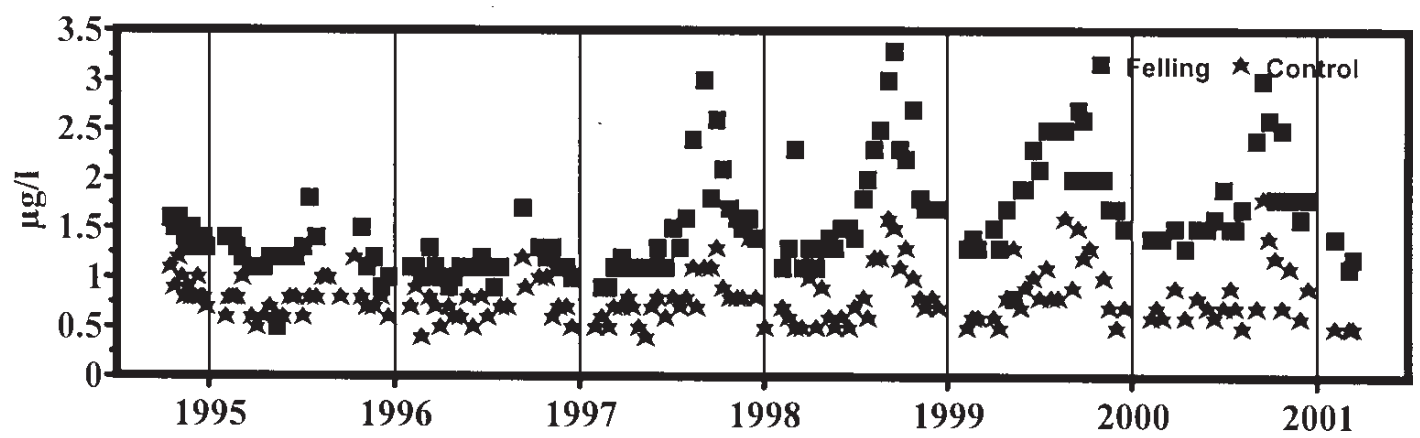

Fig. A2. Time series for $\mathrm{NO}_{3}, \mathrm{Cl}, \mathrm{Br}$ and I concentrations for felling and control stream sites. 
Gran Alkalinity
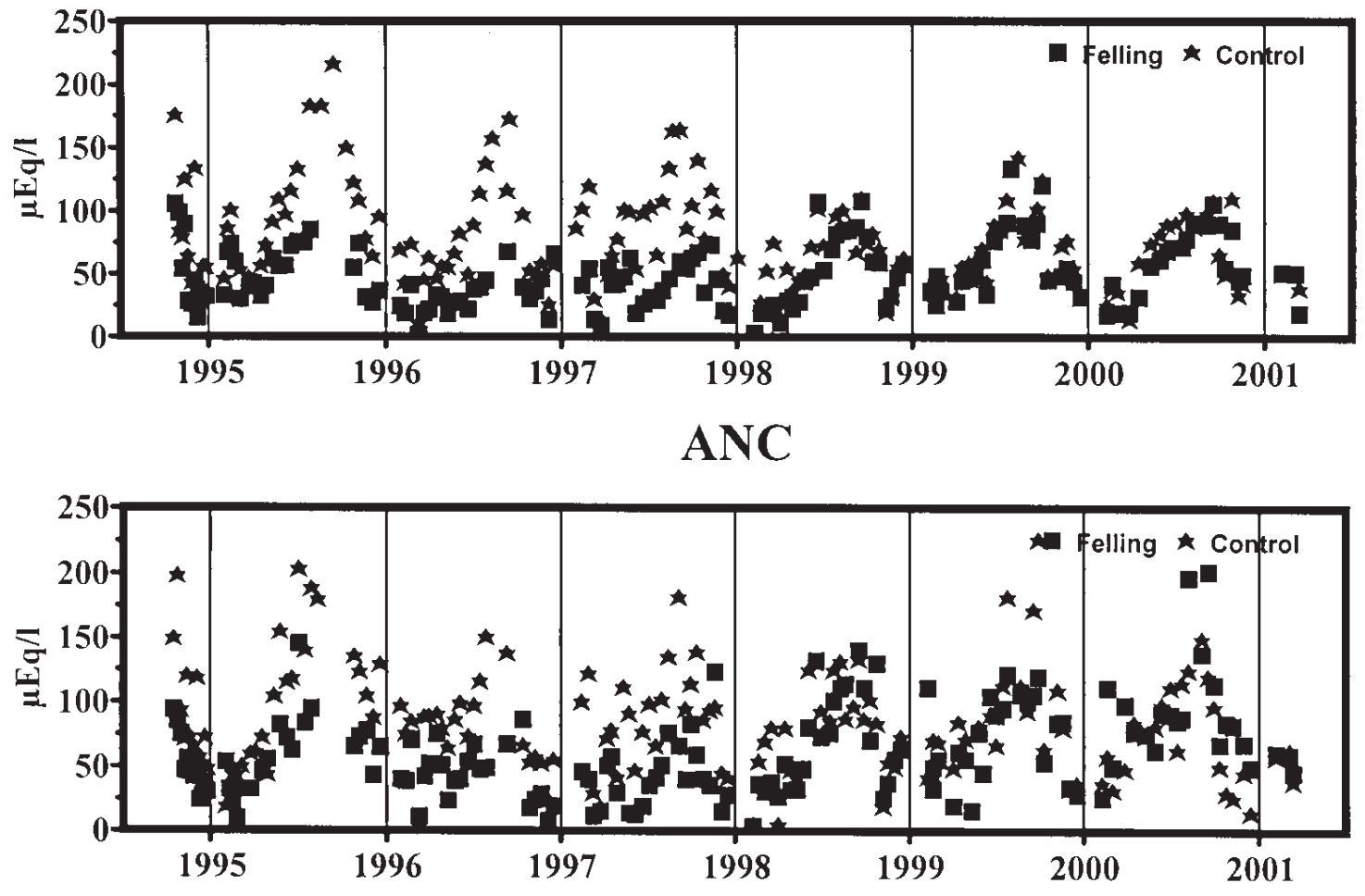

Al
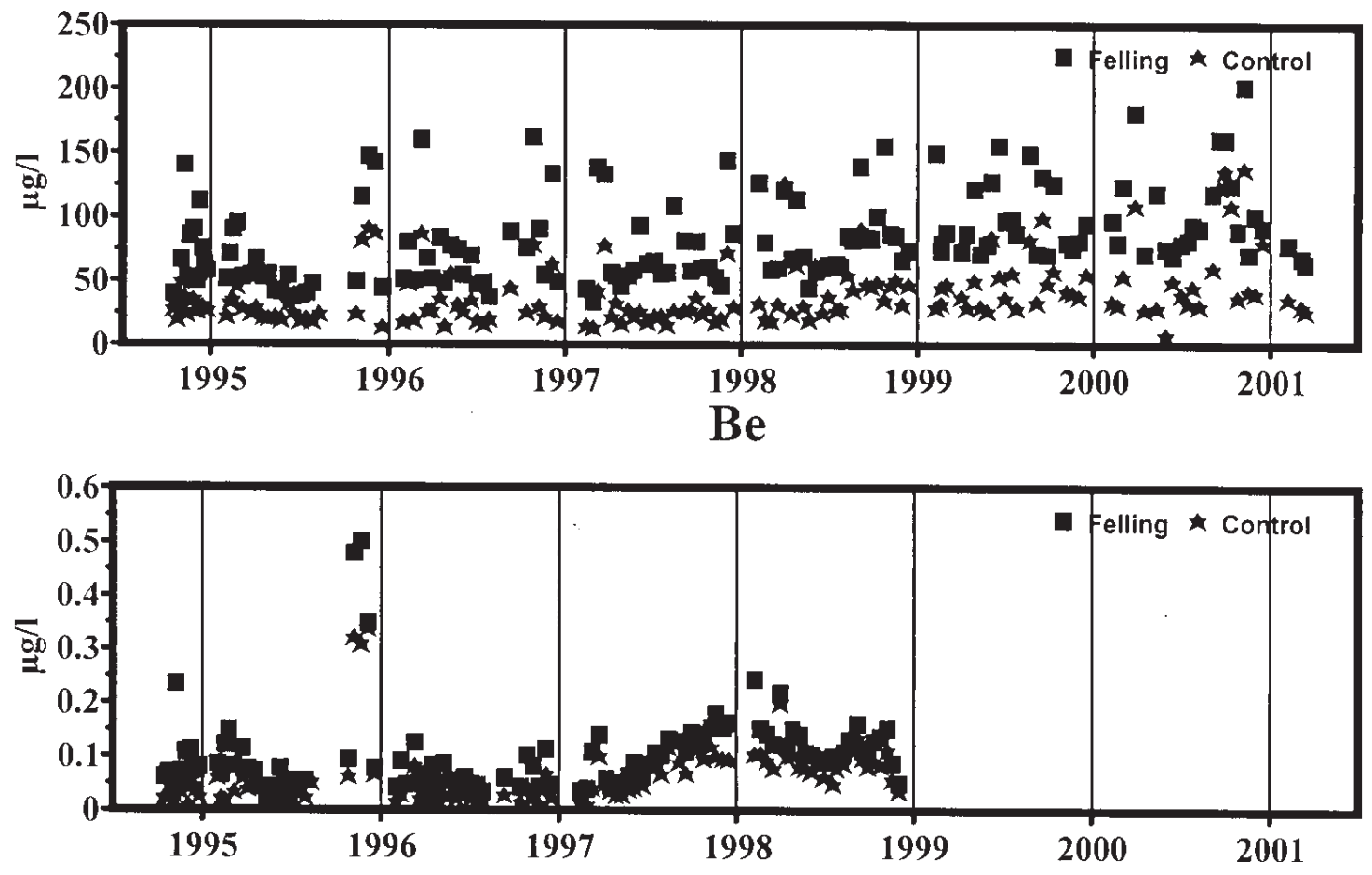

Fig. A3. Time series for $\mathrm{Y}, \mathrm{SO}_{4}, \mathrm{DOC}$ and Fe concentrations for felling and control stream sites. 

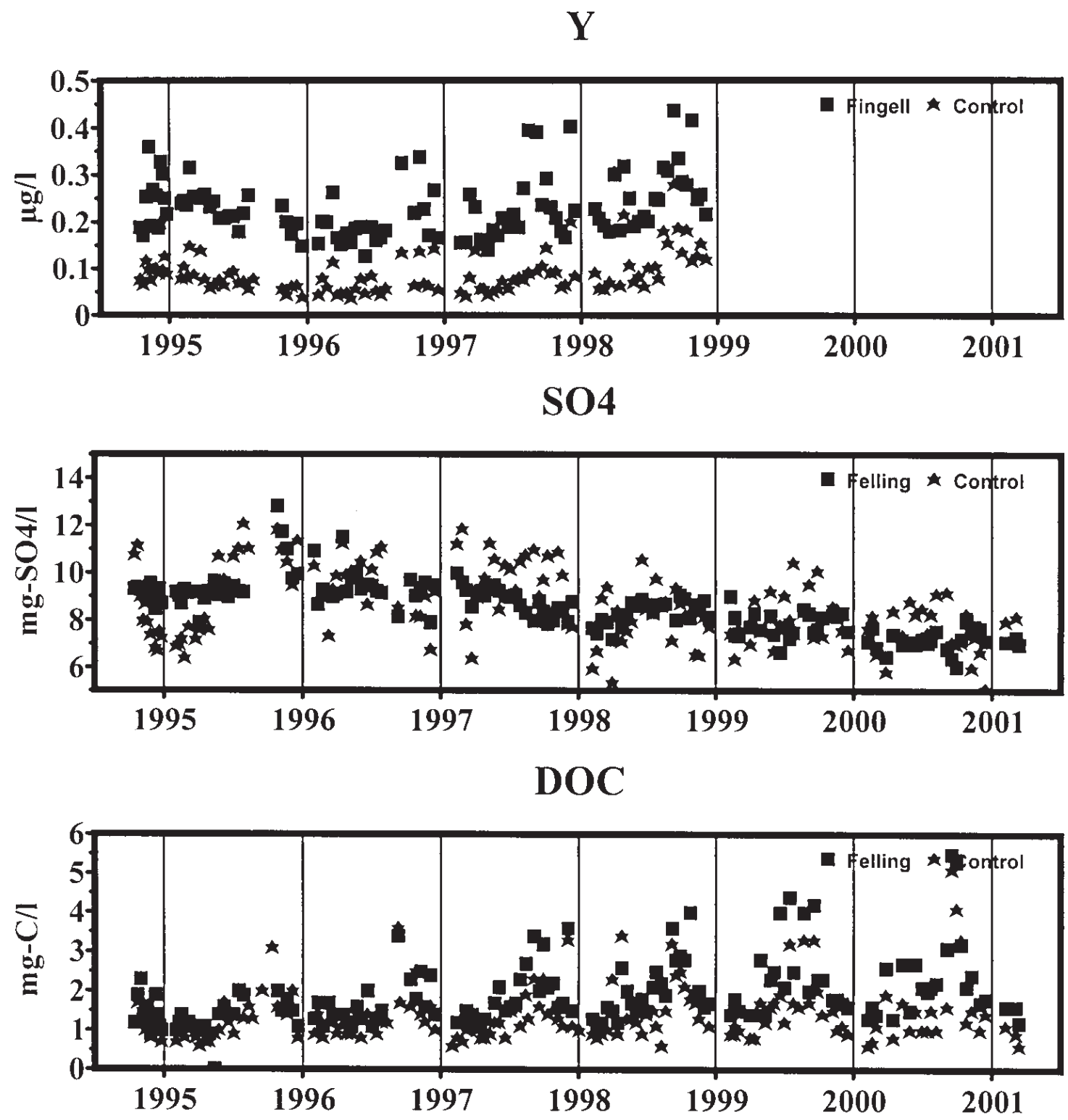

$\mathrm{Fe}$

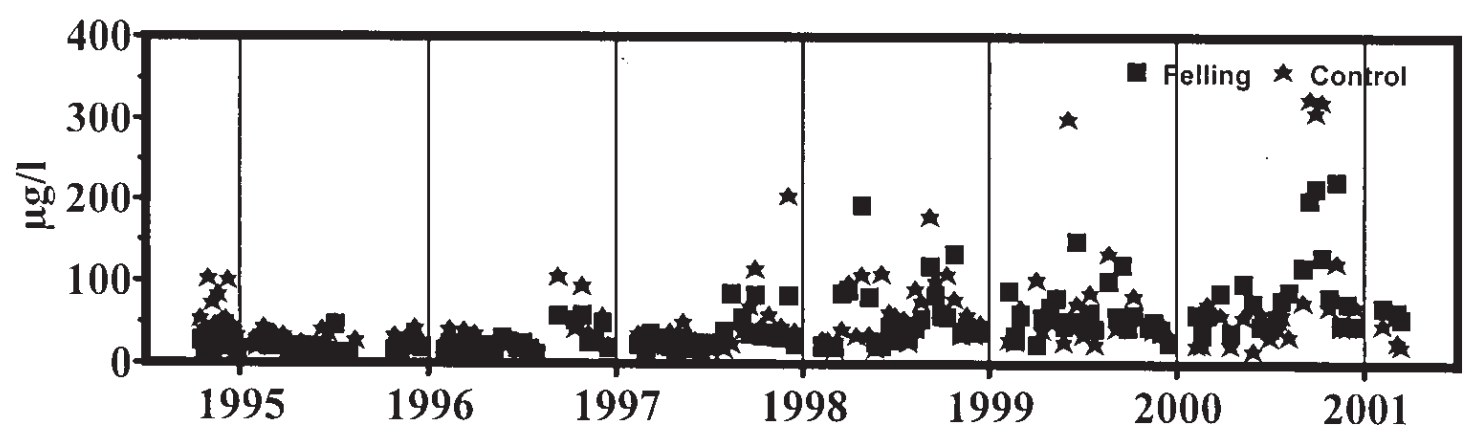

Fig. A4. Time series for Gran alkalinity, ANC, Al and Be concentrations for felling and control stream sites. 

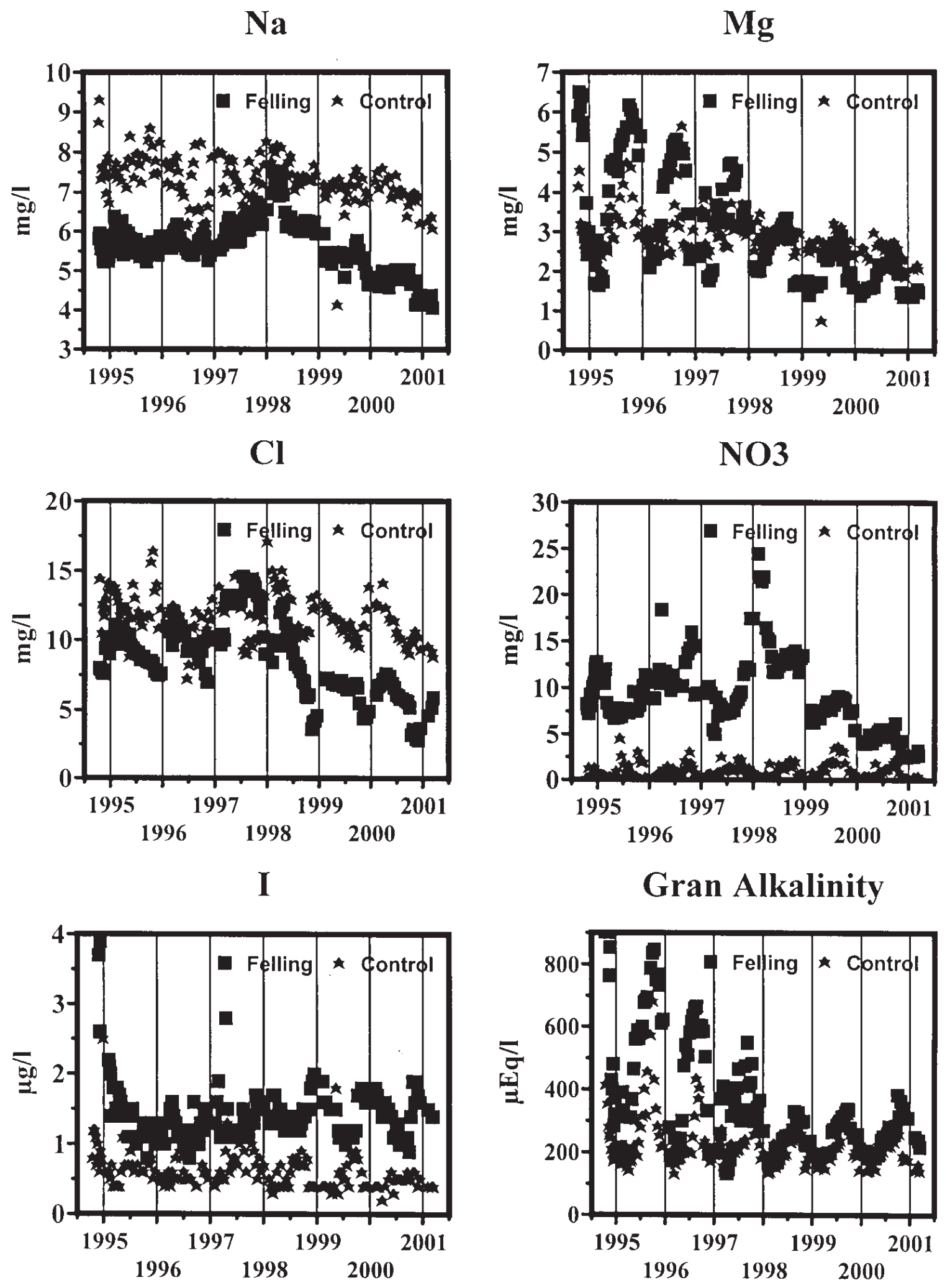

Fig. A5. Time series for $\mathrm{Na}, \mathrm{Mg}, \mathrm{Cl}, \mathrm{NO}_{3}$, I and Gran alkalinity for felling and control ground water sites. 
Colin Neal, Brian Reynolds, Margaret Neal and Bronwen Williams

Table A1. Statistical summary of rainfall chemistry for the monitoring period October 1994 to February 2001.

\begin{tabular}{|c|c|c|c|c|c|}
\hline & & Average & Median & Minimum & Maximum \\
\hline $\mathrm{Na}$ & $\mathrm{mg} \mathrm{l}^{-1}$ & 1.93 & 1.54 & 0.30 & 6.73 \\
\hline K & $\mathrm{mg} \mathrm{l}^{-1}$ & 0.29 & 0.16 & 0.00 & 6.54 \\
\hline $\mathrm{Ca}$ & $\mathrm{mg} \mathrm{l}^{-1}$ & 0.82 & 0.51 & 0.09 & 5.50 \\
\hline $\mathrm{Mg}$ & $\mathrm{mg} \mathrm{l}^{-1}$ & 0.32 & 0.27 & 0.04 & 2.63 \\
\hline $\mathrm{NH}_{4}$ & $\mathrm{mg}-\mathrm{NH}_{4} \mathrm{l}^{-1}$ & 0.88 & 0.38 & 0.01 & 14.2 \\
\hline $\mathrm{Cl}$ & $\mathrm{mg} \mathrm{l}^{-1}$ & 4.26 & 3.85 & 0.50 & 11.2 \\
\hline $\mathrm{SO}_{4}$ & $\mathrm{mg}-\mathrm{SO}_{4} \mathrm{l}^{-1}$ & 2.12 & 1.69 & 0.59 & 14.0 \\
\hline $\mathrm{NO}_{3}$ & $\mathrm{mg}-\mathrm{NO}_{3} \mathrm{l}^{-1}$ & 2.27 & 0.95 & 0.10 & 35.0 \\
\hline $\mathrm{F}$ & $\mathrm{mg} \mathrm{l}^{-1}$ & 0.02 & 0.02 & 0.00 & 0.07 \\
\hline $\mathrm{Br}$ & $\mu g \mathrm{l}^{-1}$ & 11.8 & 10.5 & 0.0 & 41.0 \\
\hline I & $\mu \mathrm{g} \mathrm{1^{-1 }}$ & 1.1 & 1.0 & 0.3 & 4.4 \\
\hline $\mathrm{PO}_{4}$ & $\mathrm{mg}-\mathrm{P} \mathrm{l}^{-1}$ & 0.03 & 0.00 & 0.00 & 2.05 \\
\hline DOC & $\mathrm{mg} \mathrm{l}^{-1}$ & 1.09 & 0.90 & 0.00 & 3.90 \\
\hline $\mathrm{Si}$ & $\mathrm{mg} \mathrm{l}^{-1}$ & 0.11 & 0.00 & 0.00 & 1.85 \\
\hline $\mathrm{pH}$ & & 5.34 & 5.26 & 3.95 & 7.41 \\
\hline G. Alk & $\mu \mathrm{Eq}^{-1}$ & 40.8 & -2.4 & -147.6 & 1832 \\
\hline ANC & $\mu \mathrm{Eq} \mathrm{l}^{-1}$ & -42.3 & -20.2 & -2615 & 123 \\
\hline $\mathrm{EpCO}_{2}$ & atmos & na & na & na & na \\
\hline $\mathrm{Al}$ & $\mu \mathrm{g} \mathrm{l}^{-1}$ & 16 & 9 & 0 & 111 \\
\hline B & $\mu \mathrm{g} \mathrm{l}^{-1}$ & 3.3 & 3.0 & 0.0 & 10.9 \\
\hline $\mathrm{Ba}$ & $\mu \mathrm{g} \mathrm{l}^{-1}$ & 1.8 & 1.4 & 0.2 & 10.0 \\
\hline $\mathrm{Be}$ & $\mu \mathrm{g} \mathrm{l}^{-1}$ & 0.0 & 0.0 & 0.0 & 0.2 \\
\hline $\mathrm{Cd}$ & $\mu g \mathrm{l}^{-1}$ & 0.4 & 0.4 & 0.0 & 2.1 \\
\hline $\mathrm{Ce}$ & $\mu \mathrm{g} \mathrm{l}^{-1}$ & 0.0 & 0.0 & 0.0 & 0.1 \\
\hline Co & $\mu g 1^{-1}$ & 0.1 & 0.1 & 0.0 & 0.2 \\
\hline $\mathrm{Cr}$ & $\mu \mathrm{g} \mathrm{l}^{-1}$ & 3.9 & 0.8 & 0.0 & 41.7 \\
\hline $\mathrm{Cs}$ & $\mu \mathrm{g} \mathrm{l}^{-1}$ & 0.0 & 0.0 & 0.0 & 0.1 \\
\hline $\mathrm{Cu}$ & $\mu g 1^{-1}$ & 2.8 & 2.4 & 0.2 & 11 \\
\hline $\mathrm{Fe}$ & $\mu \mathrm{g} \mathrm{l}^{-1}$ & 19.8 & 10.1 & 0.0 & 246 \\
\hline $\mathrm{La}$ & $\mu \mathrm{g} \mathrm{l}^{-1}$ & 0.0 & 0.0 & 0.0 & 0.0 \\
\hline $\mathrm{Li}$ & $\mu \mathrm{g} \mathrm{l}^{-1}$ & 0.1 & 0.1 & 0.0 & 0.6 \\
\hline $\mathrm{Mn}$ & $\mu \mathrm{g} \mathrm{l}^{-1}$ & 5.7 & 3.5 & 0.0 & 97 \\
\hline Mo & $\mu \mathrm{g} \mathrm{l}^{-1}$ & 0.1 & 0.1 & 0.0 & 0.9 \\
\hline $\mathrm{Ni}$ & $\mu \mathrm{g} \mathrm{l}^{-1}$ & 1.5 & 1.1 & 0.0 & 9.4 \\
\hline $\mathrm{Pb}$ & $\mu \mathrm{g}^{-1}$ & 92 & 22 & 1 & 749 \\
\hline $\operatorname{Pr}$ & $\mu \mathrm{g} \mathrm{l}^{-1}$ & 0.0 & 0.0 & 0.0 & 0.0 \\
\hline $\mathrm{Rb}$ & $\mu \mathrm{g} \mathrm{l}^{-1}$ & 0.2 & 0.2 & 0.0 & 0.7 \\
\hline $\mathrm{Sb}$ & $\mu \mathrm{g} \mathrm{l}^{-1}$ & 0.2 & 0.2 & 0.0 & 0.5 \\
\hline $\mathrm{Sc}$ & $\mu \mathrm{g} \mathrm{l}^{-1}$ & 0.0 & 0.0 & 0.0 & 0.1 \\
\hline $\mathrm{Sr}$ & $\mu \mathrm{g} \mathrm{l}^{-1}$ & 2.8 & 2.4 & 0.6 & 14.3 \\
\hline $\mathrm{Th}$ & $\mu \mathrm{g} \mathrm{l}^{-1}$ & 0.0 & 0.0 & 0.0 & 0.3 \\
\hline $\mathrm{U}$ & $\mu \mathrm{g} \mathrm{l}^{-1}$ & 0.0 & 0.0 & 0.0 & 0.0 \\
\hline $\mathrm{Y}$ & $\mu \mathrm{g} \mathrm{l}^{-1}$ & 0.0 & 0.0 & 0.0 & 0.0 \\
\hline $\mathrm{Zn}$ & $\mu \mathrm{g} \mathrm{l}^{-1}$ & 19.4 & 16.2 & 1.6 & 84.3 \\
\hline
\end{tabular}


The hydrochemistry of plantation spruce forest catchments with brown earth soils, Vyrnwy in mid-Wales

Table A2. Stream water statistics for the monitoring period October 1994 to February 2001.

\begin{tabular}{|c|c|c|c|c|c|c|c|}
\hline & & \multicolumn{3}{|c|}{ Stream: Felling } & \multicolumn{3}{|c|}{ Stream: Control } \\
\hline & & Average & $\operatorname{Min}$ & $\operatorname{Max}$ & Average & Min & $\operatorname{Max}$ \\
\hline $\mathrm{Na}$ & $\mathrm{mg} \mathrm{l}^{-1}$ & 5.23 & 3.60 & 6.49 & 5.75 & 3.55 & 7.21 \\
\hline K & $\mathrm{mg} \mathrm{l}^{-1}$ & 0.36 & 0.00 & 4.14 & 0.33 & 0.21 & 0.57 \\
\hline $\mathrm{Ca}$ & $\mathrm{mg} \mathrm{l}^{-1}$ & 3.66 & 0.51 & 4.98 & 3.06 & 0.57 & 5.22 \\
\hline $\mathrm{Mg}$ & $\mathrm{mg} \mathrm{l}^{-1}$ & 1.20 & 0.61 & 1.66 & 1.85 & 0.66 & 2.77 \\
\hline $\mathrm{NH}_{4}$ & $\mathrm{mg}-\mathrm{NH}_{4} \mathrm{l}^{-1}$ & 0.04 & 0.00 & 0.86 & 0.03 & 0.00 & 0.13 \\
\hline $\mathrm{Cl}$ & $\mathrm{mg} \mathrm{l}^{-1}$ & 8.64 & 4.90 & 13.20 & 9.34 & 6.00 & 13.50 \\
\hline $\mathrm{SO}_{4}$ & $\mathrm{mg}-\mathrm{SO}_{4} \mathrm{l}^{-1}$ & 8.60 & 2.34 & 24.20 & 8.70 & 3.64 & 12.34 \\
\hline $\mathrm{NO}_{3}$ & $\mathrm{mg}-\mathrm{NO}_{3} \mathrm{l}^{-1}$ & 2.23 & 0.00 & 10.80 & 2.00 & 0.85 & 4.70 \\
\hline $\mathrm{F}$ & $\mathrm{mg} \mathrm{l}^{-1}$ & 0.05 & 0.00 & 0.11 & 0.04 & 0.00 & 0.10 \\
\hline $\mathrm{Br}$ & $\mu g 1^{-1}$ & 42 & 14 & 94 & 32 & 17 & 88 \\
\hline I & $\mu g \mathrm{l}^{-1}$ & 1.55 & 0.50 & 3.30 & 0.81 & 0.40 & 1.80 \\
\hline $\mathrm{PO}_{4}$ & $\mathrm{mg}-\mathrm{P} \mathrm{l}^{-1}$ & 0.01 & 0.00 & 0.08 & 0.01 & 0.00 & 0.06 \\
\hline DOC & $\mathrm{mg} \mathrm{l}^{-1}$ & 1.9 & 0.0 & 5.5 & 1.4 & 0.6 & 5.1 \\
\hline $\mathrm{Si}$ & $\mathrm{mg} \mathrm{l}^{-1}$ & 1.8 & 0.9 & 3.1 & 1.9 & 0.7 & 2.9 \\
\hline $\mathrm{pH}$ & & 6.29 & 5.40 & 7.20 & 6.71 & 5.74 & 7.53 \\
\hline G. Alk & $\mu \mathrm{Eq} 1^{-1}$ & 50 & 2 & 134 & 77 & 3 & 216 \\
\hline ANC & $\mu \mathrm{Eq}^{1^{-1}}$ & 62 & -6 & $20-202$ & 83 & -15 & 226 \\
\hline $\mathrm{EpCO}_{2}$ & atmos & 4 & 1 & 22 & 2 & 1 & 13 \\
\hline $\mathrm{Al}$ & $\mu \mathrm{g} \mathrm{l}^{-1}$ & 82.9 & 31.8 & 202.1 & 38.7 & 7.6 & 137.6 \\
\hline B & $\mu \mathrm{g}^{-1}$ & 7.7 & 3.4 & 33.4 & 5.9 & 3.3 & 10.8 \\
\hline $\mathrm{Ba}$ & $\mu \mathrm{gl}^{-1}$ & 6.5 & 3.6 & 19.5 & 3.6 & 2.6 & 11.7 \\
\hline $\mathrm{Be}$ & $\mu \mathrm{gl}^{-1}$ & 0.0 & 0.0 & 0.5 & 0.0 & 0.0 & 0.3 \\
\hline $\mathrm{Cd}$ & $\mu \mathrm{gl}^{-1}$ & 0.2 & 0.0 & 2.0 & 0.2 & 0 & 1.5 \\
\hline $\mathrm{Ce}$ & $\mu \mathrm{gl}^{-1}$ & 0.1 & 0.0 & 0.3 & 0.0 & 0.0 & 0.1 \\
\hline Co & $\mu \mathrm{gl}^{-1}$ & 0.2 & 0.0 & 2.5 & 0.1 & 0.0 & 2.1 \\
\hline $\mathrm{Cr}$ & $\mu \mathrm{gl}^{-1}$ & 0.2 & 0.0 & 2.3 & 0.2 & 0.0 & 4.4 \\
\hline Cs & $\mu g \mathrm{l}^{-1}$ & 0.0 & 0.0 & 1.7 & 0.2 & 0.1 & 9.8 \\
\hline $\mathrm{Cu}$ & $\mu \mathrm{gl}^{-1}$ & 2.1 & 0.0 & 17.2 & 1.7 & 0.0 & 6.4 \\
\hline $\mathrm{Fe}$ & $\mu \mathrm{gl}^{-1}$ & 50.9 & 9.4 & 570.8 & 60.8 & 6.6 & 1312 \\
\hline $\mathrm{La}$ & $\mu g \mathrm{l}^{-1}$ & 0.1 & 0.0 & 0.1 & 0.1 & 0.0 & 0.1 \\
\hline $\mathrm{Li}$ & $\mu \mathrm{gl}^{-1}$ & 0.8 & 0.3 & 4.0 & 1.0 & 0.6 & 1.4 \\
\hline $\mathrm{Mn}$ & $\mu \mathrm{gl}^{-1}$ & 10.0 & 0.4 & 74.1 & 6.9 & 0.0 & 180 \\
\hline Mo & $\mu \mathrm{g} \mathrm{l}^{-1}$ & 0.1 & 0.0 & 2.3 & 0.1 & 0.0 & 1.5 \\
\hline $\mathrm{Ni}$ & $\mu \mathrm{gl}^{-1}$ & 1.4 & 0.0 & 8.1 & 1.5 & 0.0 & 9.9 \\
\hline $\mathrm{Pb}$ & $\mu \mathrm{gl}^{-1}$ & 0.2 & 0.0 & 17.8 & 0.8 & 0.0 & 24.3 \\
\hline $\operatorname{Pr}$ & $\mu \mathrm{g} \mathrm{l}^{-1}$ & 0.0 & 0.0 & 0.1 & 0.1 & 0.0 & 0.2 \\
\hline $\mathrm{Rb}$ & $\mu \mathrm{gl}^{-1}$ & 0.3 & 0.1 & 0.8 & 0.5 & 0.3 & 0.7 \\
\hline $\mathrm{Sb}$ & $\mu \mathrm{gl}^{-1}$ & 0.1 & 0.0 & 1.6 & 2.5 & 0.4 & 8.0 \\
\hline $\mathrm{Sc}$ & $\mu \mathrm{gl}^{-1}$ & 0.7 & 0.2 & 4.3 & 0.7 & 0.4 & 1.3 \\
\hline $\mathrm{Sr}$ & $\mu g 1^{-1}$ & 11.0 & 8.3 & 41.8 & 11.2 & 7.2 & 18.3 \\
\hline Th & $\mu \mathrm{gl}^{-1}$ & 0.0 & 0.0 & 0.3 & 0.1 & 0.2 & 1.4 \\
\hline $\mathrm{U}$ & $\mu \mathrm{gl}^{-1}$ & 0.0 & 0.0 & 0.0 & 1.0 & 0.0 & 3.5 \\
\hline Y & $\mu g l^{-1}$ & 0.2 & 0.1 & 0.4 & 0.1 & 0.0 & 0.3 \\
\hline $\mathrm{Zn}$ & $\mu \mathrm{gl}^{-1}$ & 9.5 & 1.1 & 54.6 & 8.4 & 1.0 & 89.3 \\
\hline
\end{tabular}


Colin Neal, Brian Reynolds, Margaret Neal and Bronwen Williams

Table A3. Ground water chemistry summary for the monitoring period October 1994 to February 2001.

\begin{tabular}{|c|c|c|c|c|c|c|c|}
\hline & & \multicolumn{3}{|c|}{ Borehole: Felling } & \multicolumn{3}{|c|}{ Borehole: Control } \\
\hline & & Average & Minimum & Maximum & Average & Minimum & Maximum \\
\hline $\mathrm{Na}$ & $\mathrm{mg} \mathrm{l}^{-1}$ & 5.86 & 4.06 & 7.5 & 7.30 & 4.14 & 9.31 \\
\hline K & $\mathrm{mg} \mathrm{l}^{-1}$ & 0.91 & 0.55 & 3.20 & 0.34 & 0.18 & 0.90 \\
\hline $\mathrm{Ca}$ & $\mathrm{mg} \mathrm{l}^{-1}$ & 9.52 & 1.78 & 16.1 & 5.45 & 1.09 & 11.4 \\
\hline $\mathrm{Mg}$ & $\mathrm{mg} \mathrm{l}^{-1}$ & 3.11 & 1.38 & 6.51 & 2.93 & 0.75 & 5.68 \\
\hline $\mathrm{NH}_{4}$ & $\mathrm{mg}-\mathrm{NH}_{4} \mathrm{l}^{-1}$ & 0.05 & 0.00 & 3.40 & 0.02 & 0.00 & 0.09 \\
\hline $\mathrm{Cl}$ & $\mathrm{mg} \mathrm{l}^{-1}$ & 9.0 & 2.80 & 54.0 & 11.6 & 6.90 & 17.1 \\
\hline $\mathrm{SO}_{4}$ & $\mathrm{mg}-\mathrm{SO}_{4} \mathrm{l}^{-1}$ & 11.5 & 8.49 & 19.7 & 12.4 & 4.66 & 18.4 \\
\hline $\mathrm{NO}_{3}$ & $\mathrm{mg}-\mathrm{NO}_{3} \mathrm{l}^{-1}$ & 9.39 & 0.70 & 24.50 & 1.03 & 0.00 & 4.50 \\
\hline $\mathrm{F}$ & $\mathrm{mg} \mathrm{l}^{-1}$ & 0.07 & 0.02 & 0.13 & 0.04 & 0.00 & 0.09 \\
\hline $\mathrm{Br}$ & $\mu g \mathrm{l}^{-1}$ & 42 & 6 & 180 & 47 & 17 & 70 \\
\hline I & $\mu g ~^{-1}$ & 2.0 & 0.5 & 18.0 & 0.7 & 0.2 & 2.5 \\
\hline $\mathrm{PO}_{4}$ & $\mathrm{mg}-\mathrm{P}^{-1}$ & 0.05 & 0.00 & 0.14 & 0.01 & 0.00 & 0.08 \\
\hline DOC & $\mathrm{mg} \mathrm{l}^{-1}$ & 0.79 & 0.30 & 4.30 & 1.09 & 0.00 & 4.20 \\
\hline $\mathrm{Si}$ & $\mathrm{mg} \mathrm{l}^{-1}$ & 1.94 & 0.00 & 3.60 & 2.34 & 1.30 & 3.90 \\
\hline $\mathrm{pH}$ & & 6.02 & 5.44 & 6.60 & 7.00 & 6.21 & 7.98 \\
\hline G. Alk & $\mu \mathrm{Eq} \mathrm{l}^{-1}$ & 361 & 134 & 924 & 230 & 130 & 682 \\
\hline ANC & $\mu \mathrm{Eq} \mathrm{l}^{-1}$ & 368 & 85 & 1016 & 239 & 93 & 695 \\
\hline $\mathrm{EpCO}_{2}$ & atmos & 54 & 20 & 123 & 4 & 1 & 20 \\
\hline $\mathrm{Al}$ & $\mu \mathrm{g} \mathrm{l}^{-1}$ & 15.7 & 0.0 & 215 & 26.4 & 2.1 & 787 \\
\hline B & $\mu g 1^{-1}$ & 13.9 & 1.0 & 128 & 7.4 & 2.9 & 12.3 \\
\hline $\mathrm{Ba}$ & $\mu \mathrm{g} \mathrm{l}^{-1}$ & 9.7 & 0.4 & 89.5 & 0.9 & 0.2 & 3.9 \\
\hline $\mathrm{Be}$ & $\mu \mathrm{g}^{-1}$ & 0.1 & 0.0 & 1.0 & 0.0 & 0.0 & 0.5 \\
\hline $\mathrm{Cd}$ & $\mu \mathrm{g}^{-1}$ & 0.3 & 0.0 & 1.7 & 0.2 & 0.0 & 1.4 \\
\hline $\mathrm{Ce}$ & $\mu \mathrm{g}^{-1}$ & 0.0 & 0.0 & 0.5 & 0.1 & 0.0 & 1.8 \\
\hline Co & $\mu \mathrm{g}^{-1}$ & 0.4 & 0.0 & 19.3 & 0.1 & 0.0 & 2.1 \\
\hline $\mathrm{Cr}$ & $\mu \mathrm{gl}^{-1}$ & 0.1 & 0.0 & 1.9 & 0.2 & 0.0 & 12.9 \\
\hline Cs & $\mu g 1^{-1}$ & 0.1 & 0.0 & 0.4 & 0.3 & 0.0 & 14.6 \\
\hline $\mathrm{Cu}$ & $\mu \mathrm{g}^{-1}$ & 3.0 & 0.0 & 9.7 & 3.6 & 0.0 & 10.7 \\
\hline $\mathrm{Fe}$ & $\mu \mathrm{gl}^{-1}$ & 18.2 & 0.0 & 386 & 35.6 & 1.2 & 1016 \\
\hline $\mathrm{La}$ & $\mu \mathrm{g} \mathrm{l}^{-1}$ & 0.0 & 0.0 & 0.2 & 0.0 & 0.0 & 0.6 \\
\hline $\mathrm{Li}$ & $\mu \mathrm{g}^{-1}$ & 1.8 & 0.0 & 23.1 & 1.2 & 0.7 & 4.2 \\
\hline $\mathrm{Mn}$ & $\mu \mathrm{g}^{-1}$ & 18.1 & 0.7 & 280.7 & 3.2 & 0.0 & 89.8 \\
\hline Mo & $\mu \mathrm{g} \mathrm{l}^{-1}$ & 0.2 & 0.0 & 2.8 & 0.2 & 0.0 & 11.5 \\
\hline $\mathrm{Ni}$ & $\mu g 1^{-1}$ & 3.0 & 0.0 & 47.5 & 1.5 & 0.0 & 28.3 \\
\hline $\mathrm{Pb}$ & $\mu \mathrm{g} \mathrm{l}^{-1}$ & 0.2 & 0.0 & 1.9 & 0.3 & 0.0 & 14.8 \\
\hline $\operatorname{Pr}$ & $\mu \mathrm{g} \mathrm{l}^{-1}$ & 0.0 & 0.0 & 0.1 & 0.0 & 0.0 & 0.2 \\
\hline $\mathrm{Rb}$ & $\mu \mathrm{g}^{-1}$ & 1.0 & 0.0 & 6.7 & 0.4 & 0.2 & 0.9 \\
\hline $\mathrm{Sb}$ & $\mu \mathrm{g} \mathrm{l}^{-1}$ & 0.3 & 0.0 & 9.9 & 0.1 & 0.0 & 2.3 \\
\hline $\mathrm{Sc}$ & $\mu \mathrm{g} \mathrm{l}^{-1}$ & 0.8 & 0.0 & 9.2 & 0.8 & 0.4 & 1.8 \\
\hline $\mathrm{Sr}$ & $\mu g 1^{-1}$ & 19.4 & 0.4 & 115 & 19.9 & 13.7 & 37.6 \\
\hline Th & $\mu \mathrm{g} \mathrm{l}^{-1}$ & 0.0 & 0.0 & 1.1 & 0.0 & 0.0 & 0.9 \\
\hline $\mathrm{U}$ & $\mu \mathrm{g} \mathrm{l}^{-1}$ & 0.1 & 0.0 & 0.1 & 0.0 & 0.0 & 0.2 \\
\hline Y & $\mu \mathrm{g}^{-1}$ & 0.2 & 0.0 & 0.4 & 0.1 & 0.0 & 0.5 \\
\hline $\mathrm{Zn}$ & $\mu \mathrm{g} \mathrm{l}^{-1}$ & 17.0 & 6.0 & 83.2 & 9.4 & 2.5 & 29.5 \\
\hline
\end{tabular}

